\title{
Groundwater quality of an hard rock aquifer in the Subledu Basin of Khammam district, India
}

\author{
Vulloju Narasaiah $^{1}$ D $\cdot$ Bekkam Venkateswara Rao ${ }^{1}$
}

Received: 5 June 2020 / Accepted: 4 May 2021 / Published online: 21 May 2021

(C) The Author(s) 2021

\begin{abstract}
Hard rock aquifers of Indian peninsula are loaded with excess nitrate due to heavy use of fertilizers during irrigation and excess fluoride due to the geogenic contamination. This study is focused on the groundwater quality in Subledu Basin in view of the large-scale use of groundwater for both irrigation and drinking purposes as no such study was carried out earlier in the basin. The study area is located at Khammam district, Telangana state, India, which is a hard rock terrain mostly covered with granites and gneisses. Twenty-two groundwater samples were collected covering the entire basin in the month of May 2019 from running hand pumps for analyzing the major anions and cations in the groundwater. The samples were analyzed by using standard gravimetric method for evaluation of total dissolved solids; titrimetric methods to analyze carbonates, bicarbonates and chloride; UV spectrometric method for estimation of nitrate; and ion-selective electrode method for fluoride and spectrophotometer for sulfate and phosphate. These chemical constituents are used to calculate parameters, namely total hardness, sodium adsorption ratio, residual sodium carbonate, sodium percentage, Kelley's ratio and magnesium hazard. The spatial distribution maps of important chemical constituents are prepared by using the contour maps created by utilizing the inverse distance weighted interpolation tool in the Geographical Information System. The excess fluoride values of $2.84 \mathrm{mg} / \mathrm{l}, 2.76 \mathrm{mg} / \mathrm{l}$ and $1.87 \mathrm{mg} / \mathrm{l}$ are observed in the villages of Pocharam, Kistapuram and Turakagudem, respectively, as against the maximum permissible concentration of $1.5 \mathrm{mg} / \mathrm{l}$ prescribed by World Health Organization. Excess use of fertilizers for agriculture is causing the nitrate pollution of groundwater in more than $50 \%$ of the samples with concentrations ranging from a minimum of $2 \mathrm{mg} / \mathrm{l}$ to a maximum of $460 \mathrm{mg} / \mathrm{l}$ in the villages of Medidapalle and Bachodu. It is identified that the total hardness is ranging between 200 and $820 \mathrm{mg} / \mathrm{l}$ which is very high when compared with the Bureau of Indian Standards. Based on sodium adsorption ratio, residual sodium carbonate, Kelley's ratio, and sodium percentage analyses, two samples were not suitable for irrigation. Similarly, 13 samples are not suitable for drinking water purposes based on the excess presence of fluoride and nitrate. Groundwater quality maps of Subledu Basin depicting the areas suitable or not for the irrigation as well as for drinking purposes were prepared. From these maps, it is found that groundwater from large parts of the basin is not suitable for drinking purposes while for irrigation purposes it is suitable.
\end{abstract}

Keywords Quality of groundwater · Hard rock aquifer · Subledu basin

\section{Introduction}

Groundwater is the main source for irrigation, domestic and drinking purposes in many basins of the Indian peninsula (Siva Prasad and Venkateswara Rao 2018). Groundwater plays an important role for supplying the water to irrigation in Subledu Basin even though there are many tanks

Vulloju Narasaiah

narsijntuh@gmail.com

1 Centre for Water Resources, Institute of Science and Technology, JNT University, Hyderabad, India and canals existing in the basin. Due to overirrigation, more groundwater is withdrawn; as a result, the groundwater quality also gets degraded in addition to depletion of groundwater quantity. In order to know the status of groundwater quality, groundwater samples were analyzed in the basin as no such study was carried out earlier in the basin. However, some of the studies carried out in the similar hydrogeologic settings in the Indian peninsula indicate that there are a fluoride contamination due to geogenic sources and nitrate pollution due to excess use of fertilizers are very much in vogue causing skeletal fluorosis and methemoglobinemia respectively (Mehdi et al. 2018). In order to verify the suitability of 
groundwater quality for the drinking and irrigation purposes, physicochemical analysis of water samples in the study area was carried out.

According to Vodela et al. (1997) and Moharir et al. (2017), the groundwater pollution in the world is a serious issue. In an area, the groundwater quality can be described in the form of a function which includes physical, chemical and microbiological parameters of the groundwater (Subramani et al. 2005; Schiavo et al. 2006; Magesh and Chandrasekar 2011; Krishna Kumar et al. 2011). In India, the main reason for groundwater pollution is over irrigation (Pawar and Shaikh 1995; Sujatha and Reddy 2003). The groundwater quality data give the information of groundwater recharge, discharge and storage (Walton 1970). Hydrogeochemistry information is also required to estimate the groundwater quality of an area where the groundwater is to be used for drinking and irrigation purposes (Srinivas et al. 2013). In India, nearly $80 \%$ of the rural population and around $50 \%$ of the urban population are dependent on groundwater for domestic purposes (Biswas et al. 2014). At several places, fluoride and nitrate concentrations in the groundwater of rural agricultural areas of Telangana state, India, were reported to be more than the permissible limits of World Health Organization (WHO) and Bureau of Indian Standards (BIS) (Alekhya et al. 2018; Shaik Arshad et al. 2015; Vijaya lakshmi et al. 2016; Annadasankar Roy et al. 2018).

By using the remote sensing and Geographical Information System (GIS) software, Srinivasa Rao and Jugran (2003) have prepared the groundwater quality maps as well as groundwater potential zones in the hard rock terrains of Chittoor. Inverse distance weighted (IDW) method of interpolation technique was used to generate spatial distribution maps of various irrigation water parameters (Gagandeep Singh et al. 2019).

Groundwater suitability for irrigation was assessed by salinity, chlorinity, sodicity and other parameters (Mills 2003; Nishanthiny et al. 2010). According to Chaitanya et al. (2018), spatial interpolation and statistical methods were used for mapping the groundwater quality parameters in basaltic hard rocks of Akola and Buldhana districts of Maharashtra, India. The consumption of nitrate and fluoride due to contaminated water causes the health risk, which is in the decreasing order of children, women and men. It depends upon sensitiveness to pollutants and smaller body weights of children, followed by women and men ( $\mathrm{Li}$ et al. 2016; Ahada and Suthar 2017; Yang et al. 2018; Karunanidhi et al. 2020a, b).

The present work is aimed to find out the quality of groundwater for irrigation and drinking purposes apart from verifying geogenic and anthropogenic pollution of fluoride and nitrate, respectively. The spatial distribution maps of important chemical constituents are prepared by using the contour maps created by utilizing the IDW interpolation tool in the Geographical Information System (GIS) for the drinking water quality and irrigation water quality in order to know about the polluted and nonpolluted areas as done by earlier researchers (Jasrotia et al. 2018, 2019; Adimalla and Taloor 2020).

\section{Description of the study area and methods}

\section{Location and geology}

The study area, namely Subledu Basin, is located in Khammam district, Telangana, India, as shown in Fig. 1. The areal extent of Subledu basin is $130.29 \mathrm{~km}^{2}$ and falls in the toposheet No. E44N15 and E44N16 on the 1:50,000 scale. The toposheets are collected from the Survey of India. Geographically, the area exists between the latitudes $17^{\circ} 13^{\prime} \mathrm{N}$ to $17^{\circ} 24^{\prime} \mathrm{N}$ and the longitudes $79^{\circ} 51^{\prime} \mathrm{E}$ to $79^{\circ} 59^{\prime} \mathrm{E}$.

The area of the basin is basically underlain by granites. Gray granites are exposed in the middle parts of the basin. Pink hornblende granites are prominently observed in the villages, namely Sitarampuram, Tallacheruvu, and also can be observed at eastern parts, apart from other isolated places. Pink hornblende biotite gneiss exists in the southeast of the basin. The geological map of the study area is presented in Fig. 2, and it is collected from the Geological Survey of India (GSI) Southern Region, Hyderabad. The average annual rainfall of the basin is $868 \mathrm{~mm}$ (TSDPS 2020).

\section{Topography and drainage}

Figure 3 depicts the digital elevation model (DEM) of Subledu Basin. Minimum and maximum elevation range is $55 \mathrm{~m}$ to $188 \mathrm{~m}$ above the mean sea level. The longitudinal elevation is falling from north-west to south of the basin causing the main stream flow in that direction. Similarly, the latitudinal elevations are also falling from west to center of the basin as well as east to center of the basin causing lower order streams joining the main stream from both the east and west directions.

The drainage map of the Subledu Basin (Fig. 4) indicates that the area is well drained with dendritic pattern of drainage and has considerable number of water bodies in the form of tanks and act as recharging structures.

\section{Materials and methods}

To assess the groundwater quality for drinking and irrigation purposes, 22 groundwater samples were collected in the month of May 2019. The samples were collected in one liter capacity of well-cleaned plastic bottles and sealed tightly. The samples were analyzed at Telangana State Groundwater Department, Hyderabad, using APHA (American Public 


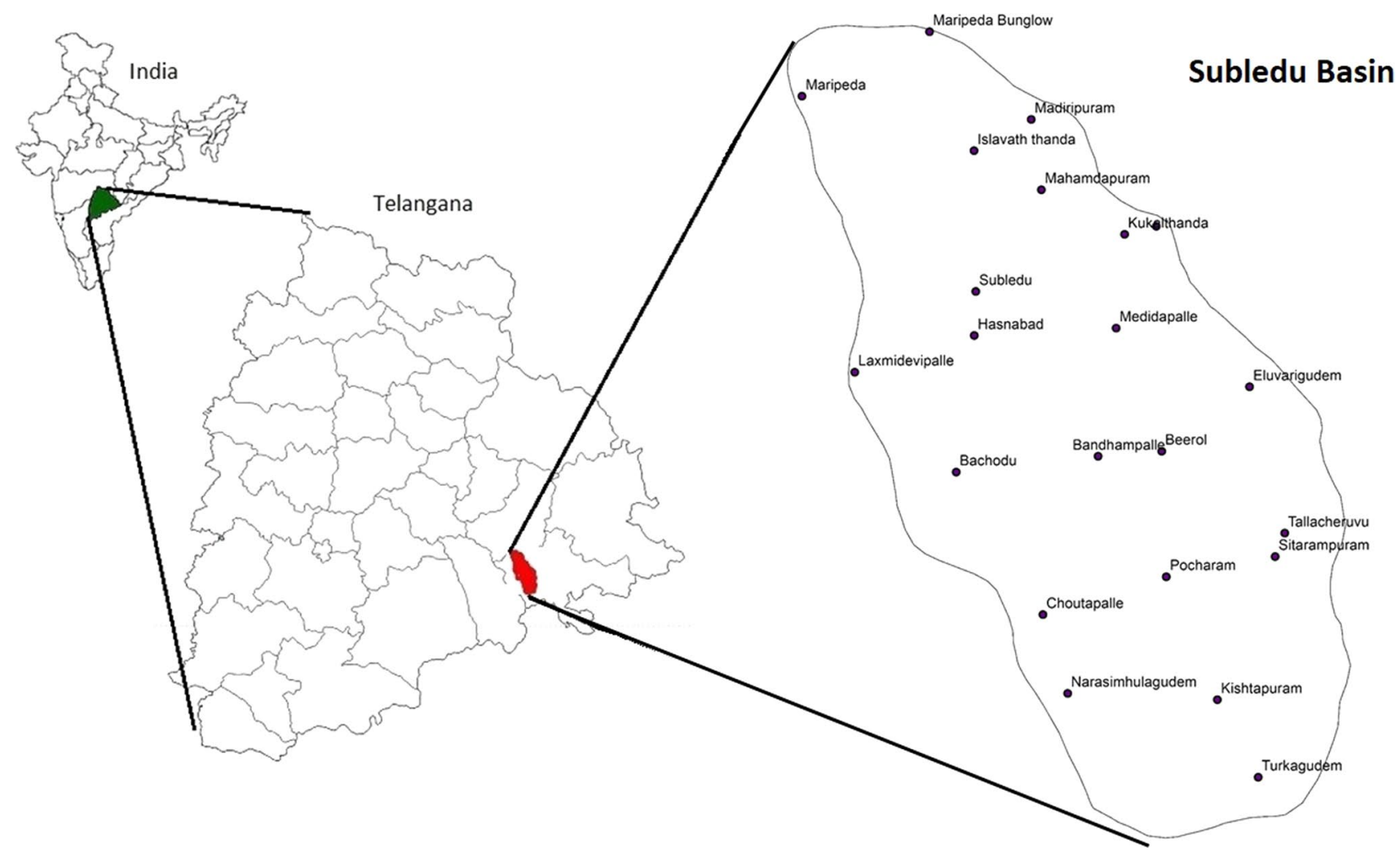

Fig. 1 Location of the study area map of Subledu Basin and the groundwater samples

Health Association 1998) methods. The results were compared with BIS (Bureau of Indian Standards 2012) values. Table 1 shows the Bureau of Indian Standards of drinking water as well as WHO (World Health Organization 2011) standards.

The major anions and cations, namely carbonate, bicarbonate, nitrate, sulfate, phosphate, sodium, potassium, fluoride, chloride, calcium and magnesium, were determined apart from other parameters such as $\mathrm{pH}$, electrical conductivity (EC) and total dissolved solids (TDS). By using the ArcGIS 10.2 software, the groundwater quality maps were also prepared and discussed. For creation of contour maps in the study area, the contour tool option was used in the spatial analyst tools of ArcGIS 10.2.

The instrument, namely Water Quality Analyzer (Elico $\mathrm{PE}$ 138), was used for determination of $\mathrm{pH}$ and electrical conductivity. Carbonate $\left(\mathrm{CO}_{3}^{-}\right)$and bicarbonate $\left(\mathrm{HCO}_{3}{ }^{-}\right)$ were determined by using acid titrimetric method. By using the spectrophotometer, the sulfate and phosphate ion concentrations were determined. For evaluation of total dissolved solids (TDS), the method of gravimetric evaporation was used. For determination of fluoride concentration, the ionselective electrode method was used and the instrument used for the analysis was ion meter. The argentometric $\left(\mathrm{AgNO}_{3}\right)$ titration method is used for chloride analysis. For the nitrate calculation, UV spectrometric method is followed. The total hardness of groundwater is estimated with EDTA titration.

In order to know the suitability of groundwater for irrigation, various derived parameters, namely sodium hazard, sodium percentage, residual sodium carbonate, magnesium hazard and Kelley's ratio, are calculated. Sodium hazard for irrigation water is determined by finding the sodium adsorption ratio (SAR). The formula for SAR is as follows.

$\mathrm{SAR}=\frac{\mathrm{Na}^{+}}{\sqrt{\frac{\mathrm{Ca}^{+2}+\mathrm{Mg}^{+2}}{2}}}$

The formula used to calculate the sodium percentage (SP) is

Sodium Percentage $=\left[\frac{\mathrm{Na}^{+}+\mathrm{K}^{+}}{\mathrm{Ca}^{+2}+\mathrm{Mg}^{+2}+\mathrm{Na}^{+}+\mathrm{K}^{+}}\right] \times 100$

According to Eaton 1950, the residual sodium carbonate can be calculated by using the formula and it can be expressed in meq/l as.

Residual Sodium Carbonate (RSC)

$$
=\left[\mathrm{HCO}_{3}^{-}+\mathrm{CO}_{3}^{-}\right]-\left[\mathrm{Ca}^{+2}+\mathrm{Mg}^{+2}\right]
$$


Fig. 2 Geology map of the Subledu Basin

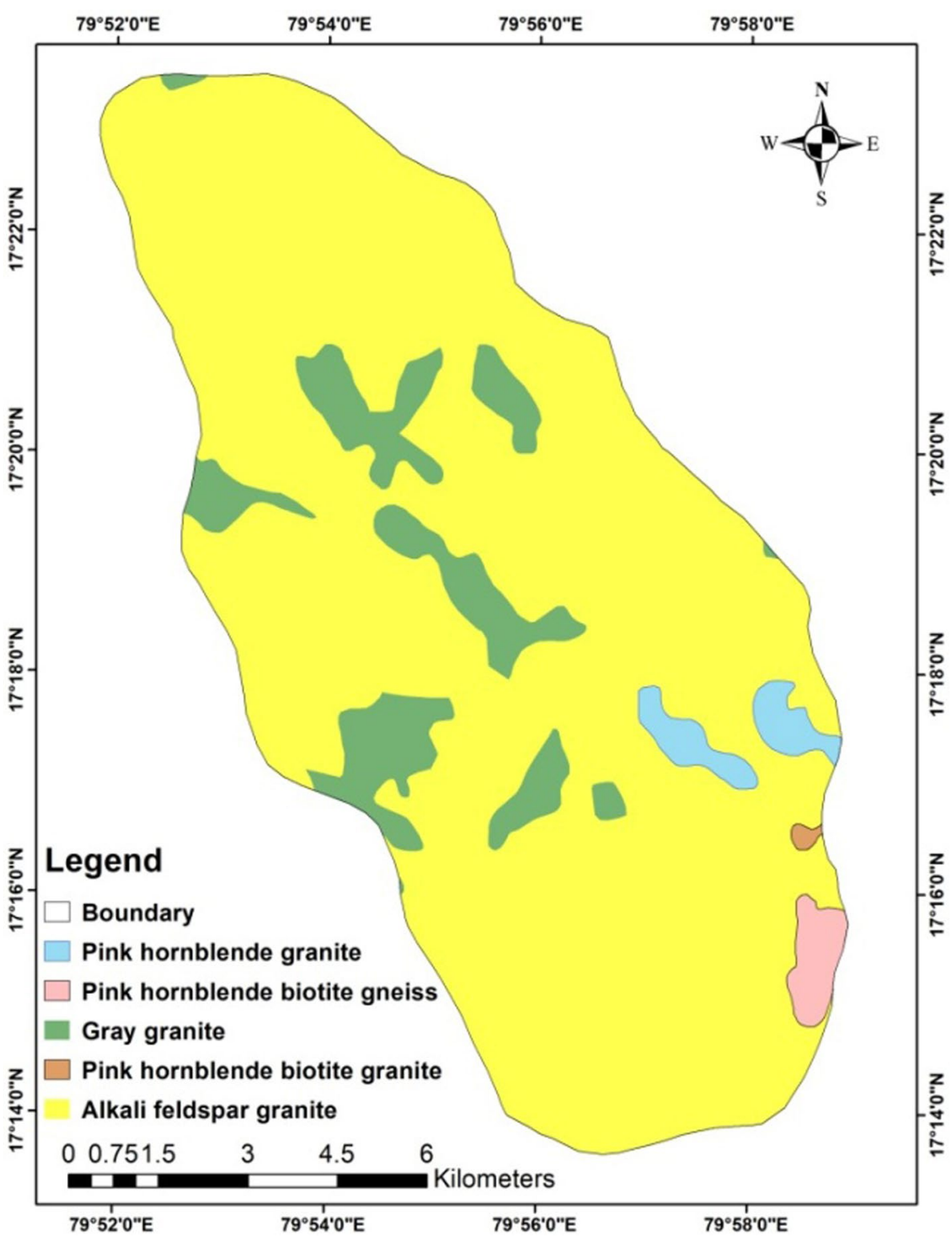

Magnesium hazard $(\mathrm{MH})$ as proposed by Szabolcs and Darab (1964) is expressed as.

$\mathrm{MH} \%=\left[\frac{\mathrm{Mg}^{+2}}{\mathrm{Ca}^{+2}+\mathrm{Mg}^{+2}}\right] \times 100$

Kelley's ratio is calculated by using the formula.

Kelley's Ratio $=\left[\frac{\mathrm{Na}^{+}}{\mathrm{Ca}^{+2}+\mathrm{Mg}^{+2}}\right]$

In all the above relations, the concentrations of anions and cations are expressed in milliequivalents per liter (meq/l).

In order to know the relative ionic dominance in the groundwater and its suitability, the hydrogeochemical data are analyzed with the piper trilinear plot and USSL diagram by using the AquaChem 4.0 software.

\section{Results and discussion}

The data so analyzed are presented in various tables. Tables 2 and 3 present the cation analysis data and the anion analysis data of groundwater samples respectively along with standard deviation, mean, variance, maximum and minimum values. From Tables 2 and 3 , the cation dominance order is $\mathrm{K}^{+}>\mathrm{Na}^{+}>\mathrm{Mg}^{+2}>\mathrm{Ca}^{+2}$. Similarly, for anions the order of dominance is $\mathrm{HCO}^{-}>\mathrm{NO}_{3}^{-}>\mathrm{Cl}^{-}>\mathrm{SO}_{4}^{-2}>\mathrm{CO}^{-2}>\mathrm{F}^{-}>\mathrm{O}-\mathrm{PO}_{4}^{-3}$. 
Fig. 3 Subledu basin digital elevation model map

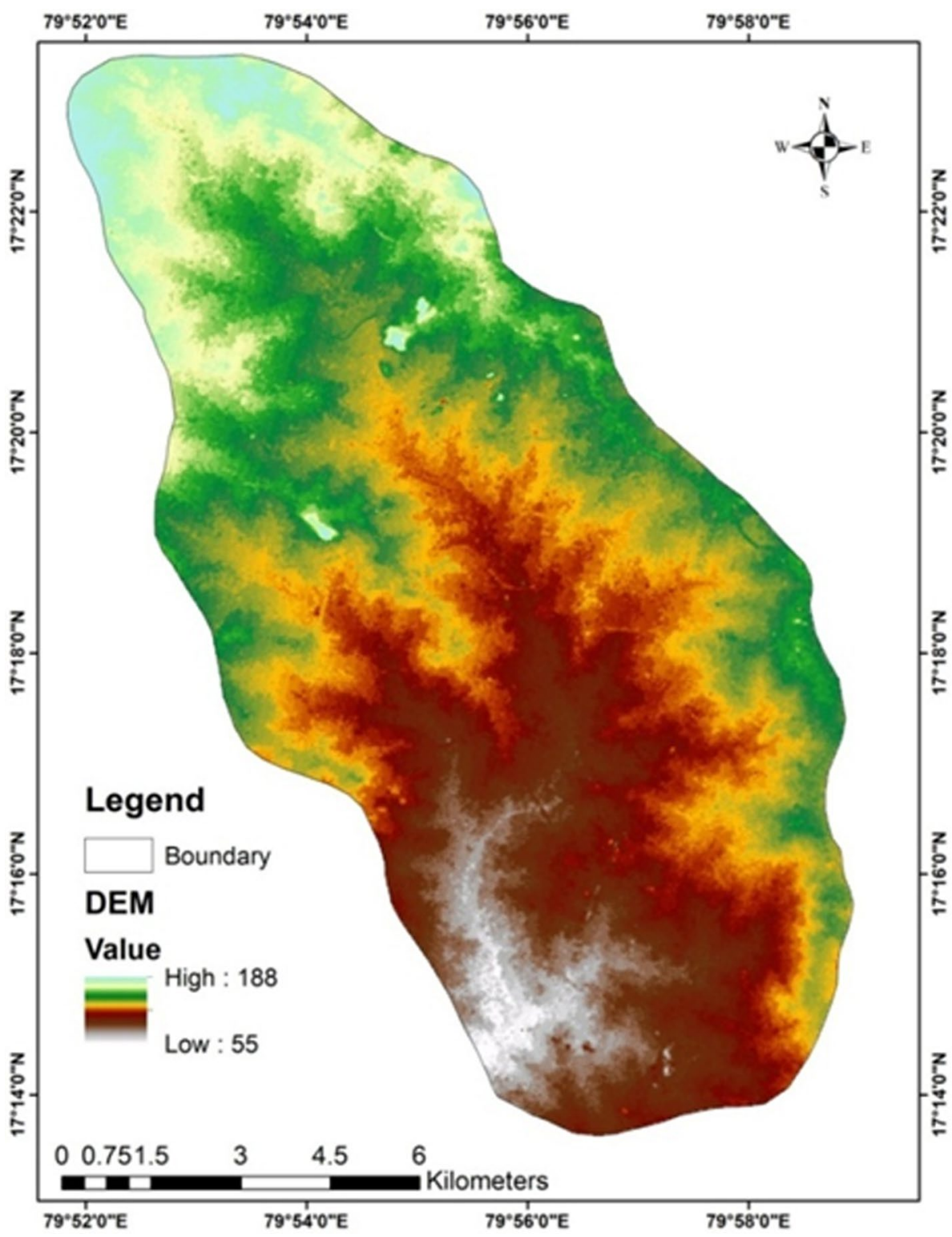

\section{Suitability of groundwater for drinking purposes}

\section{Total dissolved solids (TDS)}

In natural groundwater, a large number of salts are found dissolved. They are formed out of anion and cation combination. The major ions among them are carbonate, bicarbonate, chloride, sulfate, phosphate, nitrate, calcium, magnesium, sodium, potassium, iron, manganese, etc. TDS is a measure of the amount of material dissolved in the water. According to Mitchell and Stapp (1992), the water flow depends on TDS concentration in the organism's cells. Sometimes, death can be caused due to high or low concentration of TDS values. In order to estimate the drinking water quality, TDS plays a very important role. The water having more TDS results in salty taste. Prolonged intake of high TDS groundwater causes the kidney stones and develop heart problems (Ali and Ali 2018).

The TDS results varied from $469 \mathrm{mg} / \mathrm{l}$ at Tallacheruvu village to $1702 \mathrm{mg} / \mathrm{l}$ at Kistapuram village. The high values of TDS are due to excess usage of fertilizers for irrigation purposes, and the average value of TDS is $961 \mathrm{mg} / \mathrm{l}$. Out of 22 groundwater samples analyzed, only at two villages, namely Tallacheruvu and Madiripuram, are within the BIS limits, rest all the TDS values have exceeded the BIS limit. For TDS, the standard deviation, mean and variance are $401 \mathrm{mg} / \mathrm{l}, 961.95 \mathrm{mg} / \mathrm{l}$ and 160,806 (mg/l $)^{2}$, respectively.

From Fig. 5, it can be observed that the southern, western and northern parts of the basin are having more TDS concentration compared to the eastern part of the Basin. 
Fig. 4 Drainage map of the Subledu Basin

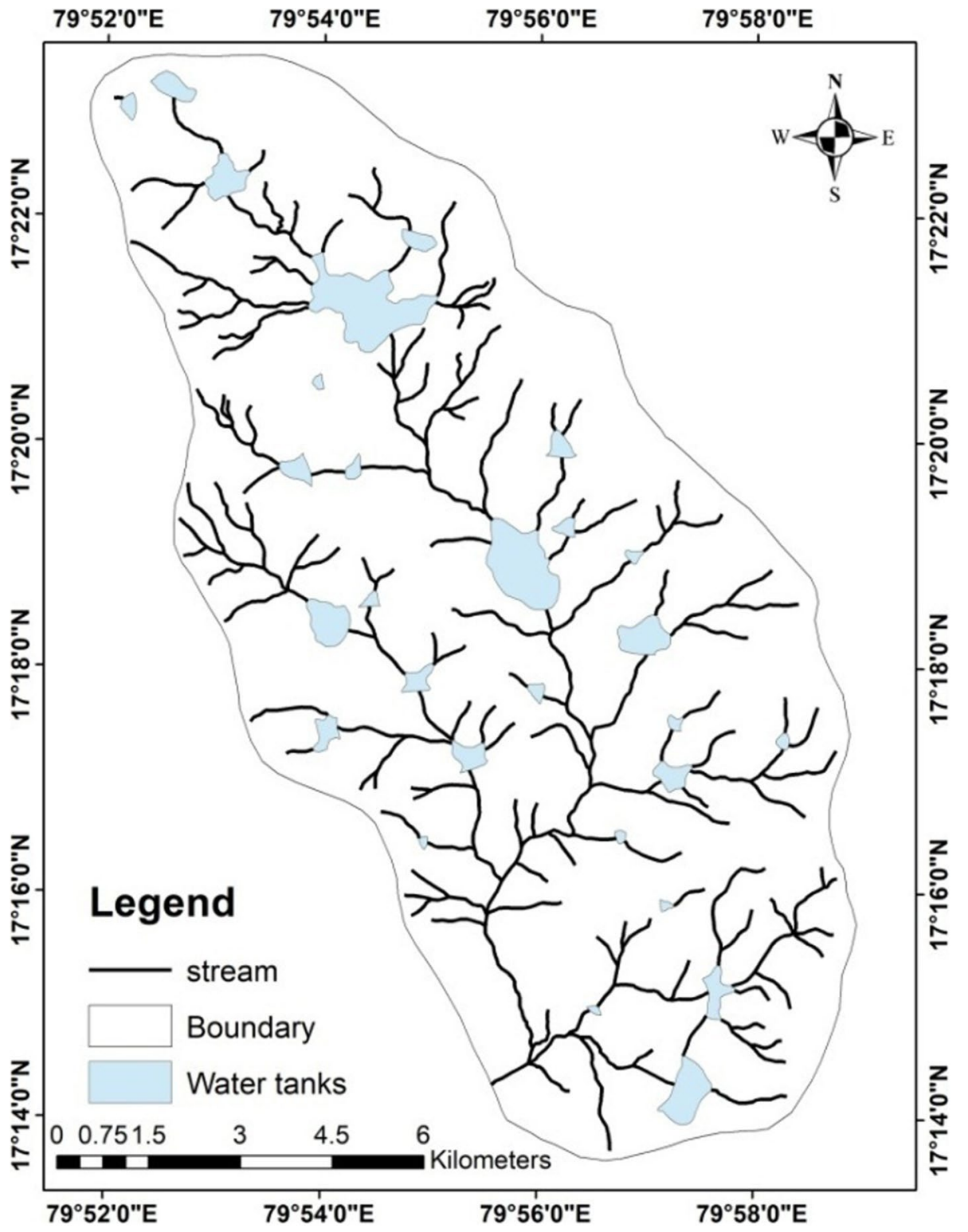

$\mathrm{pH}$

Electrical conductivity (EC)

The negative logarithmic of hydrogen ion concentration is called $\mathrm{pH}$. $\mathrm{pH}$ tells how acidic or alkaline the water is, and its values are evaluated by using the $\mathrm{pH}$ meter for all the 22 samples. If the $\mathrm{pH}$ is not in the desirable limit of 6.5-8.5 in the potable water, it harms the mucous membrane present in eyes, nose, mouth, abdomen, anus, etc. (Ibrahim et al. 2015). In the study area, $\mathrm{pH}$ values are in the range of 7.53-8.35. All the $\mathrm{pH}$ values are within the BIS range. The villages Turkagudem and Pocharam are having maximum $\mathrm{pH}$ of 8.35 value, whereas Bachodu is having the minimum $\mathrm{pH}$ of 7.53. All the values of $\mathrm{pH}$ in the basin are more than 7 which indicates that the groundwater is toward alkaline in nature. The standard deviation, mean and variance for $\mathrm{pH}$ are 0.19 , 8.09 and 0.03 , respectively.
The water can act as a conductor of electricity due to the presence of dissolved salts where as pure water cannot pass the electricity through it. The conductivity is caused in the water when the higher concentration of electrolytes are present. Conductance is measured in mhos or Siemens. In the present study, EC is varying from 733 to $2660(\mu \mathrm{S} /$ $\mathrm{cm})$. The minimum EC of $733(\mu \mathrm{S} / \mathrm{cm})$ is found at Tallacheruvu village and the maximum EC of $2660(\mu \mathrm{S} / \mathrm{cm})$ is found at Kistapuram village. The high conductivity values indicate increase in salinization of the groundwater. The standard deviation, mean and variance for EC are 626.68 $\mu \mathrm{S} / \mathrm{cm}, 1503 \mu \mathrm{S} / \mathrm{cm}$ and 392,736 $(\mu \mathrm{S} / \mathrm{cm})^{2}$, respectively. 
Table 1 Groundwater quality values of Bureau of Indian Standards (BIS) (IS 10500:2012) and WHO (2011) standards (Source: State Groundwater Department, Telangana)

\begin{tabular}{|c|c|c|c|c|c|}
\hline \multirow[t]{2}{*}{ Parameter } & \multirow[t]{2}{*}{ Units } & \multicolumn{2}{|c|}{ BIS Indian Standards (IS 10500:2012) } & \multicolumn{2}{|c|}{ WHO standard (2011) } \\
\hline & & Desirable limit & Permissible limit & Desirable limit & $\begin{array}{l}\text { Permis- } \\
\text { sible } \\
\text { limit }\end{array}$ \\
\hline $\mathrm{pH}^{*}$ & - & $6.5-8.5$ & No relaxation & $6.5-8.5$ & - \\
\hline $\mathrm{EC}$ & $(\mu \mathrm{S} / \mathrm{cm})$ & 500 & 1000 & 500 & - \\
\hline Total hardness & $(\mathrm{mg} / \mathrm{l})$ & 300 & 600 & 100 & 500 \\
\hline Chloride & $(\mathrm{mg} / \mathrm{l})$ & 250 & 1000 & 200 & 600 \\
\hline Sulfate & $(\mathrm{mg} / \mathrm{l})$ & 200 & 400 & 250 & 400 \\
\hline Nitrate & $(\mathrm{mg} / \mathrm{l})$ & 45 & No relaxation & - & 50 \\
\hline Sodium & $(\mathrm{mg} / \mathrm{l})$ & - & - & - & 200 \\
\hline Potassium & $(\mathrm{mg} / \mathrm{l})$ & - & 200 & - & 200 \\
\hline Fluoride & $(\mathrm{mg} / \mathrm{l})$ & 1.0 & 1.5 & 1.0 & 1.5 \\
\hline Total dissolved solids & $(\mathrm{mg} / \mathrm{l})$ & 500 & 2000 & - & - \\
\hline Calcium & $(\mathrm{mg} / \mathrm{l})$ & 75 & 200 & 75 & 200 \\
\hline Magnesium & $(\mathrm{mg} / \mathrm{l})$ & 30 & 100 & 50 & 150 \\
\hline Phosphate & $(\mathrm{mg} / \mathrm{l})$ & - & - & - & 0.1 \\
\hline
\end{tabular}

Except $\mathrm{pH}$ all are measured in $(\mathrm{mg} / \mathrm{l})$

Table 2 Chemical analysis of groundwater for cations and other parameters.

\begin{tabular}{|c|c|c|c|c|c|c|c|c|}
\hline S. No & Name of the Village & PH & $\mathrm{EC}(\mu \mathrm{s} / \mathrm{cm})$ & TDS (mg/l) & $\mathrm{Na}^{+}(\mathrm{mg} / \mathrm{l})$ & $\mathrm{K}^{+}(\mathrm{mg} / \mathrm{l})$ & $\mathrm{Ca}^{+2}(\mathrm{mg} / \mathrm{l})$ & $\mathrm{Mg}^{+2}(\mathrm{mg} / \mathrm{l})$ \\
\hline 1 & Maripeda & 7.77 & 887 & 568 & 30 & 2 & 80 & 44 \\
\hline 2 & Maripeda Bunglow & 8.06 & 2240 & 1434 & 287 & 6 & 64 & 83 \\
\hline 3 & Madiripuram & 8.28 & 765 & 490 & 84 & 3 & 56 & 15 \\
\hline 4 & Mahammadapuram & 8.06 & 1290 & 826 & 121 & 6 & 40 & 68 \\
\hline 5 & Subledu & 7.94 & 1756 & 1124 & 180 & 59 & 96 & 44 \\
\hline 6 & Hasnabad & 8.21 & 2060 & 1318 & 153 & 366 & 64 & 19 \\
\hline 7 & Bachodu & 7.53 & 2410 & 1542 & 172 & 18 & 112 & 131 \\
\hline 8 & Laxmidevipalle & 7.98 & 922 & 590 & 74 & 3 & 56 & 39 \\
\hline 9 & Narasimhulagudem & 8.01 & 2230 & 1427 & 212 & 5 & 40 & 136 \\
\hline 10 & Turkagudem & 8.35 & 2040 & 1306 & 204 & 6 & 16 & 131 \\
\hline 11 & Kishtapuram & 8.15 & 2660 & 1702 & 280 & 11 & 32 & 156 \\
\hline 12 & Pocharam & 8.35 & 1197 & 766 & 102 & 2 & 40 & 68 \\
\hline 13 & Tallacheruvu & 8.29 & 733 & 469 & 40 & 3 & 24 & 53 \\
\hline 14 & Beerol & 8.2 & 1056 & 676 & 72 & 29 & 40 & 58 \\
\hline 15 & Eluvarigudem & 8.24 & 938 & 600 & 51 & 2 & 24 & 73 \\
\hline 16 & Medidapalle & 8.15 & 788 & 504 & 53 & 3 & 24 & 53 \\
\hline 17 & Bandhampalle & 8.22 & 1590 & 1018 & 172 & 8 & 32 & 83 \\
\hline 18 & Mekalthanda & 8.11 & 2580 & 1651 & 265 & 6 & 16 & 165 \\
\hline 19 & Choutapalle & 7.92 & 937 & 600 & 78 & 4 & 72 & 29 \\
\hline 20 & Sitarampuram & 8.22 & 1429 & 915 & 74 & 32 & 16 & 117 \\
\hline 21 & Islavath Thanda & 7.9 & 1532 & 980 & 161 & 3 & 32 & 83 \\
\hline 22 & Kukalthanda & 8.04 & 1027 & 657 & 35 & 3 & 32 & 88 \\
\hline SD & & 0.19 & 626.68 & 401 & 79.66 & 75.30 & 25.77 & 42.57 \\
\hline Mean & & 8.09 & 1503 & 961.95 & 131.81 & 26.36 & 45.81 & 78.90 \\
\hline Variance** & & 0.03 & 392,736 & 160,806 & 6347 & 5671 & 664 & 1812 \\
\hline Maximum & & 8.35 & 2660 & 1702 & 287 & 366 & 112 & 165 \\
\hline Minimum & & 7.53 & 733 & 469 & 30 & 2 & 16 & 15 \\
\hline
\end{tabular}

**Variance is expressed in $\mathrm{mg} / \mathrm{l}^{2}$ 


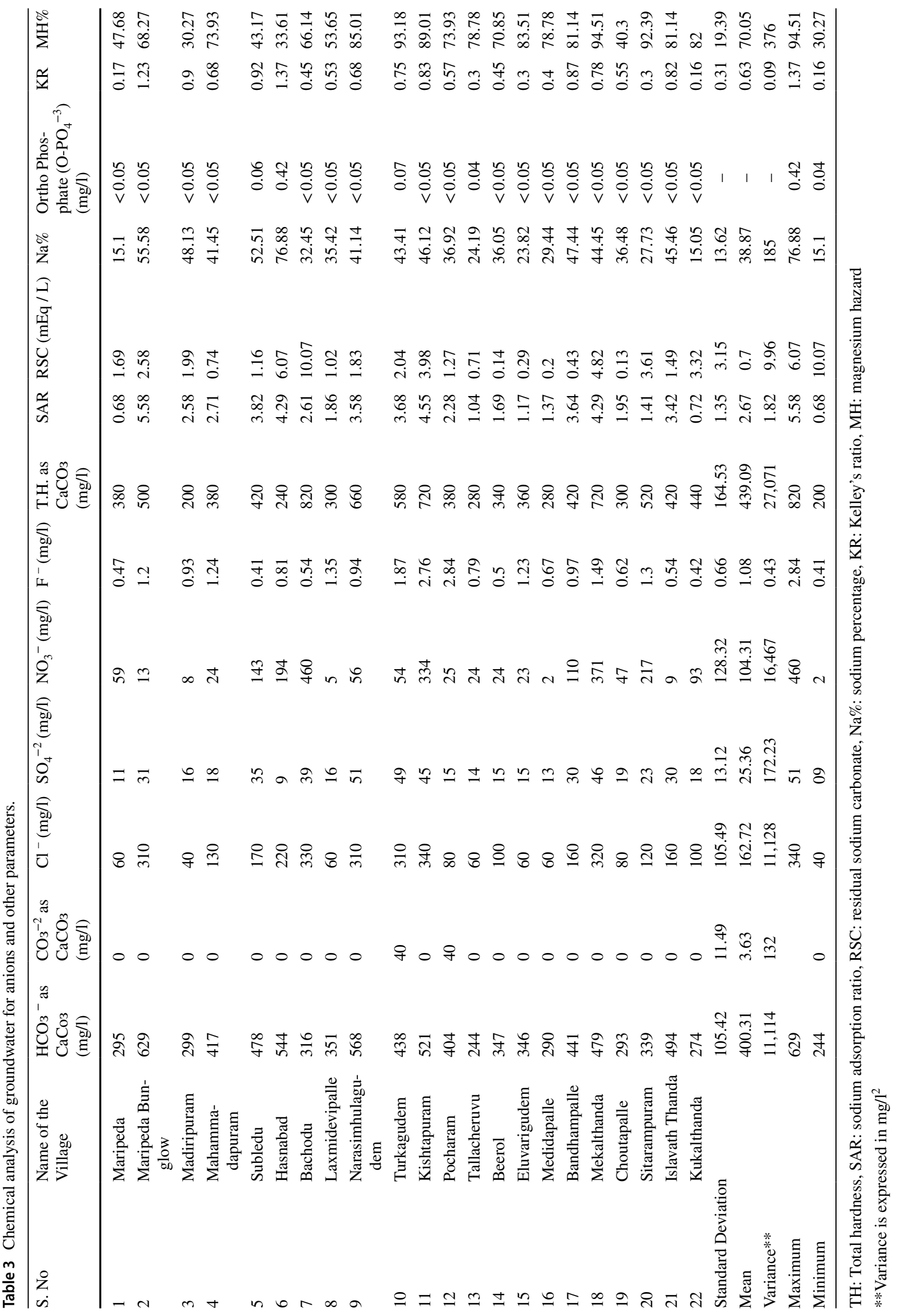


Fig. 5 Total dissolved solids distribution in the Subledu Basin

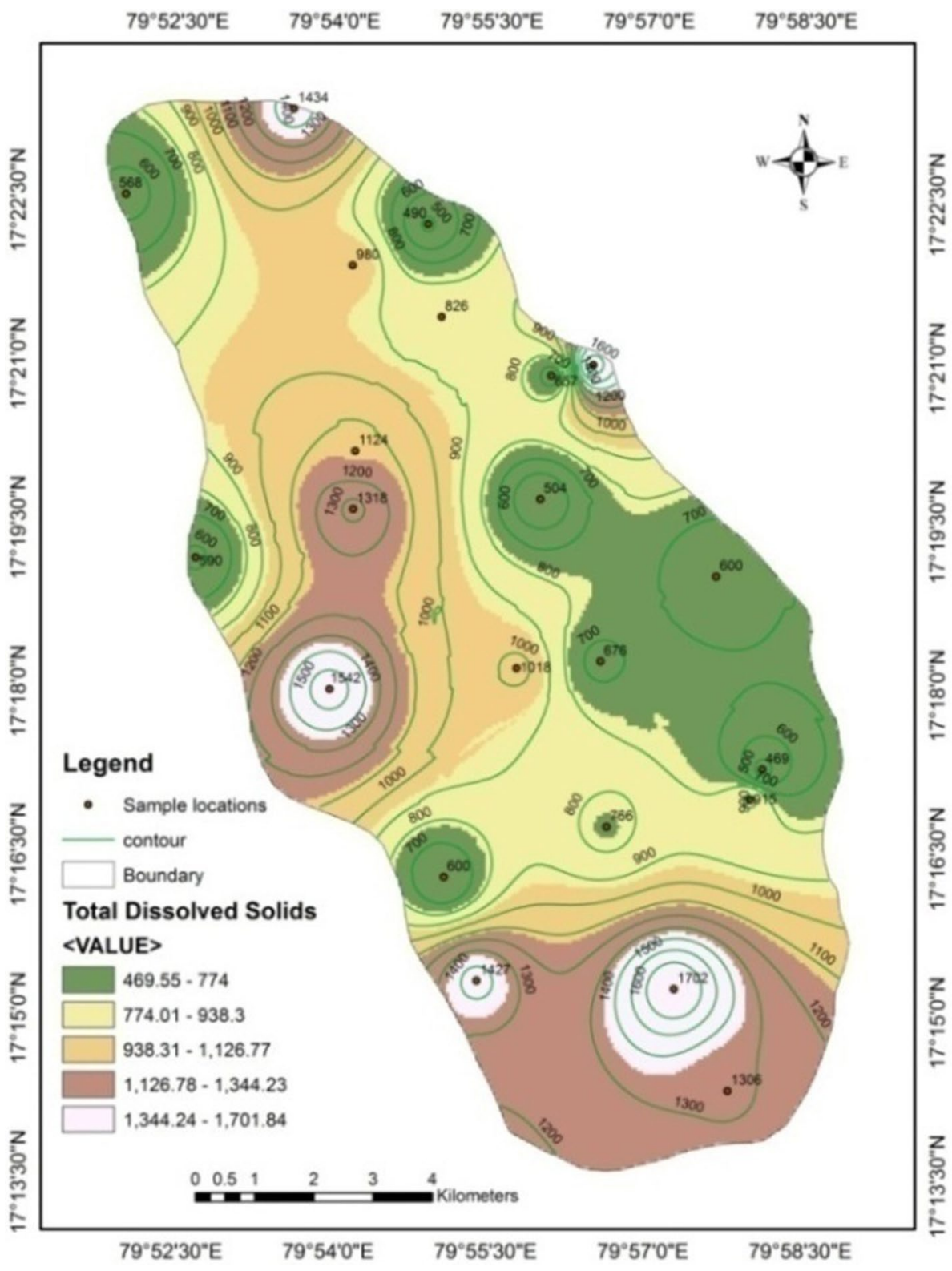

\section{Fluoride}

The presence of fluoride in the groundwater is due to the fluoride-bearing rocks like fluorspar, cryolite, fluorapatite, etc. Due to the improper presence of fluoride, dental and skeletal problems can occur. If the fluoride concentration is less than $0.4 \mathrm{mg} / \mathrm{l}$ in the drinking water, then dental fluorosis occurs but if fluoride concentration is greater than $1.5 \mathrm{mg} / 1$, skeletal fluorosis will occur (Yadav and Lata 2004). Karunanidhi et al. (2019) stated that the contamination of groundwater is caused by $\mathrm{F}^{-}$-containing minerals due to the presence of the country rocks of hornblende-biotite gneiss and granites as well as by leaching of waste disposals and uncontrolled usage of agrochemicals.

In the basin, the fluoride is ranging from 0.41 to $2.84 \mathrm{mg} / \mathrm{l}$. Except at three villages, namely Turkagudem $(1.87 \mathrm{mg} / \mathrm{l})$, Kistapuram $(2.76 \mathrm{mg} / \mathrm{l})$ and Pocharam $(2.84 \mathrm{mg} / \mathrm{l})$, the fluoride concentrations are below the $1.5 \mathrm{mg} / \mathrm{l}$ which are in permissible (BIS 2012) limit for consumption of groundwater. The standard deviation, mean and variance are $0.66 \mathrm{mg} / \mathrm{l}$, $1.08 \mathrm{mg} / \mathrm{l}$ and $0.43(\mathrm{mg} / \mathrm{l})^{2}$, respectively, for the fluoride concentration. From Fig. 6, it can be observed that the fluoride concentrations are greater than $1.5 \mathrm{mg} / \mathrm{l}$ in the southern part of the basin where it is not suitable for drinking groundwater without treatment for the fluoride. 
Fig. 6 Fluoride distribution in the Subledu Basin

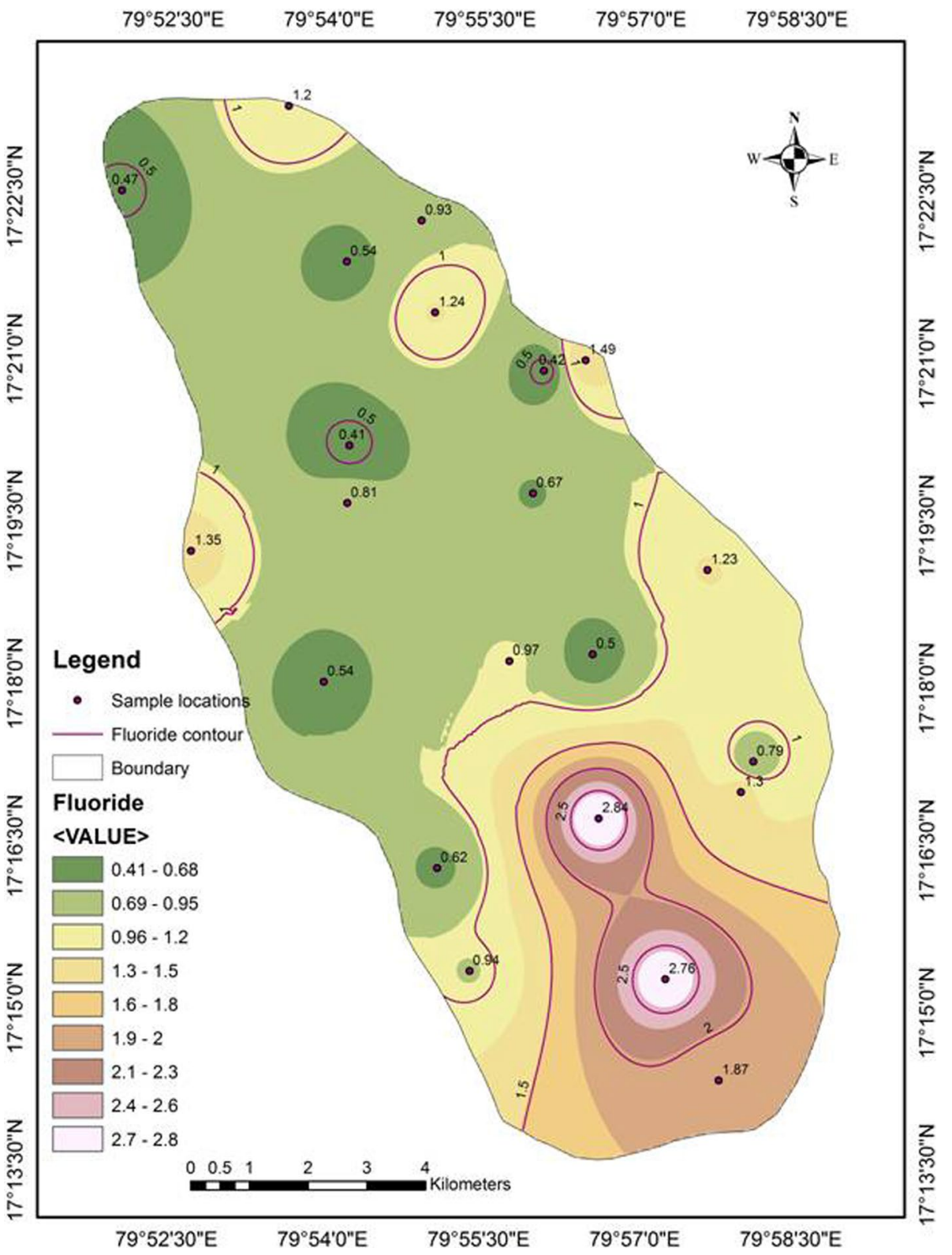

\section{Chloride}

The presence of chloride is caused in the water due to animal organic wastes. There are many reasons to cause the presence of chloride in the surface water, like effluents from water treatment plants, wastes from oil wells and agricultural wastes joining the surface water. The effect of leaching which is contaminated with the chlorides is also one of the reasons for increase in chloride concentration in the groundwater (Central Ground Water Board 2005).

The salty taste to the ground water is due to the presence of higher $\mathrm{Cl}^{-}$, and it shows a laxative effect. Most of the $\mathrm{Cl}^{-}$released from a nonlithological sources into the groundwater is due to anthropogenic sources of pollution caused by household wastewaters, (MPCA 2019;
Subba Rao et al. 2019a). Chloride causes the corrosion in the metals and also changes the taste of food products (Hilbert et al. 2006; Malcolm et al. 2017). The minimum chloride concentration of $40 \mathrm{mg} / \mathrm{l}$ is found in the village Madiripuram, and maximum chloride concentration of $340 \mathrm{mg} / \mathrm{l}$ is found in the village Kistapuram. The high concentrations of chloride are found at villages, namely Kistapuram-340 mg/l, Bachodu-330 mg/l, Mekalthanda-320 mg/l, Maripeda Bunglow, Narasimhulagudem and Turkagudem-310 mg/l. Standard deviation, mean and variance of chloride are $105.49 \mathrm{mg} / \mathrm{l}$, $162.72 \mathrm{mg} / \mathrm{l}$ and $11,128(\mathrm{mg} / \mathrm{l})^{2}$, respectively. From Fig. 7, it can be observed that high chloride concentrations are present at southern, western and some parts of north and northeast parts of the basin. 
Fig. 7 Chloride distribution in the Subledu Basin

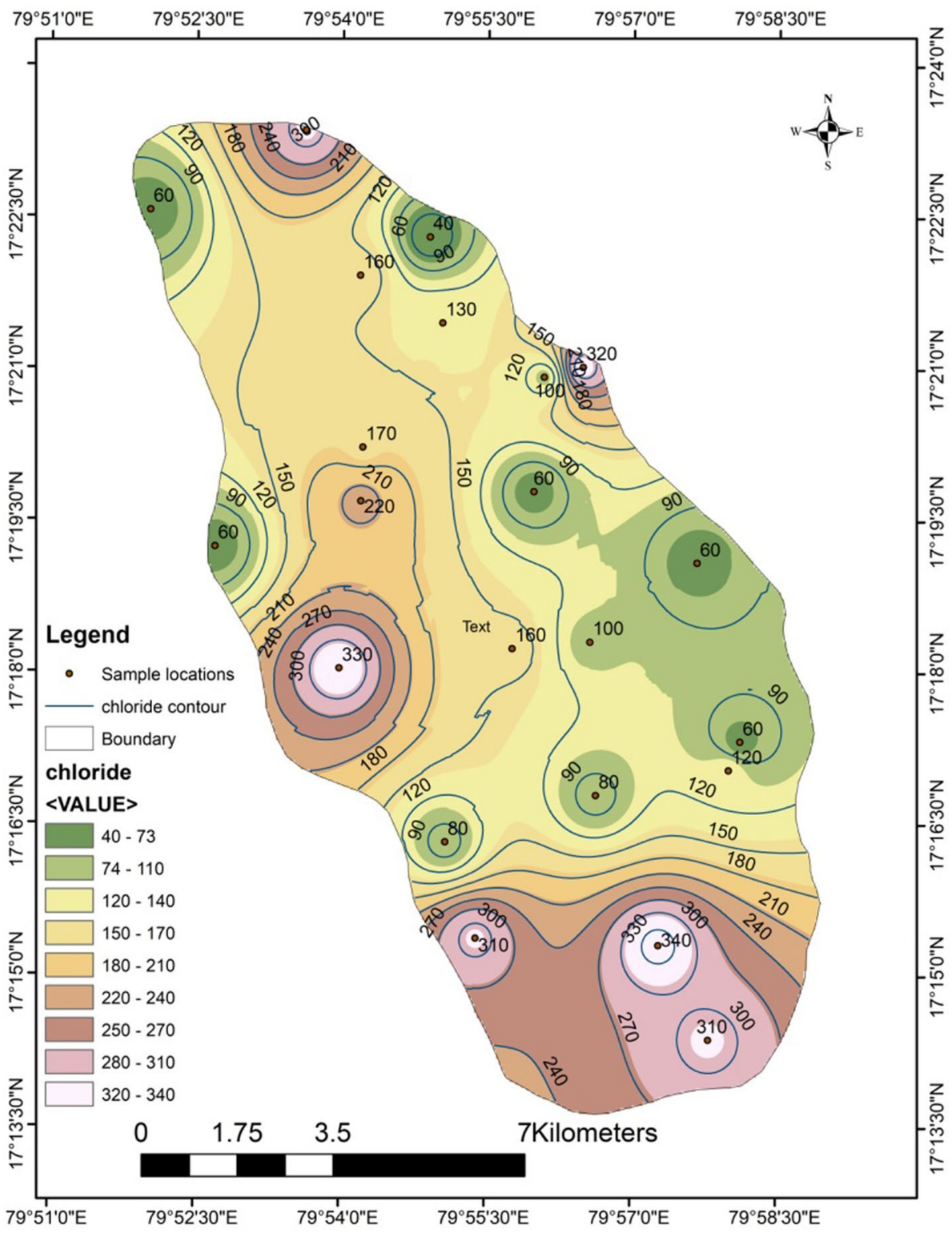

\section{Nitrate}

The nitrate contamination in the groundwater is due to the excess use of fertilizers (Sunitha 2013). The animal, human and agricultural activities create the nitrate pollution in the groundwater. According to $\mathrm{He}$ and $\mathrm{Wu}$ (2019) and $\mathrm{He}$ et al. (2019), household wastewaters and septic tank leakages as well as the soils containing the nitrogen and animal wastes are the sources of $\mathrm{NO}_{3}{ }^{-}$in the groundwater. In the drinking water, generally histomorphological changes in thyroid are observed due to the presence of $250-500 \mathrm{mg} / \mathrm{l}$ of nitrates in the groundwater for drinking (Eskiocak et al. 2005). The high concentration of nitrate in the groundwater causes the methemoglobinemia when we drink directly. Not more than $45 \mathrm{mg} / \mathrm{l}$ is allowed for drinking water. In the study area, the standard deviation, mean and variance values of nitrate are $128.32 \mathrm{mg} / 1,104.31 \mathrm{mg} / \mathrm{l}$ and $16,467(\mathrm{mg} / \mathrm{l})^{2}$, respectively.

In the present study, the nitrate concentrations range from 2 to $460 \mathrm{mg} / \mathrm{l}$. Ten groundwater samples are below $45 \mathrm{mg} / \mathrm{l}$ and another 12 groundwater samples are above $45 \mathrm{mg} / \mathrm{l}$. From Fig. 8, it can be observed that the high contamination of nitrates is in the western, southern and northeast parts of the basin. The village Medidapalle is having the low nitrate concentration of $2 \mathrm{mg} / \mathrm{l}$, while the village Bachodu is having the high nitrate concentration of $460 \mathrm{mg} / \mathrm{l}$.

\section{Calcium, magnesium and total hardness}

The $\mathrm{Ca}^{+2}$ is an essential inorganic element for proper growth of bones, which is released into the groundwater due to weathering and dissolution of plagioclase feldspars 
Fig. 8 Nitrate distribution in the Subledu Basin

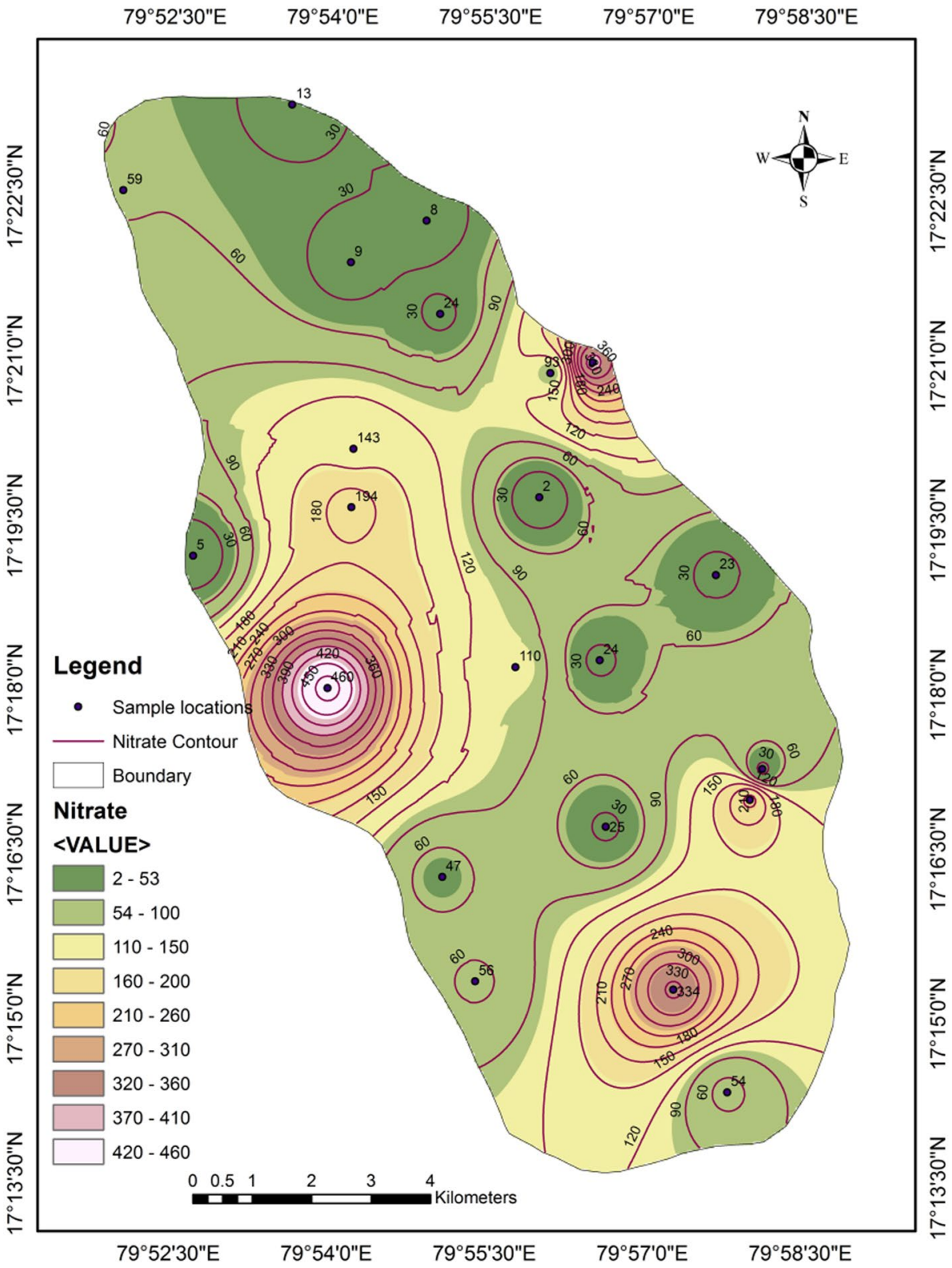

occurring in the parent rocks. The occurrence of ferromagnesium minerals (hornblende, hypersthene, sillimanite, garnet and biotite) in the basement rocks is the sources of $\mathrm{Mg}^{+2}$ in the subsurface water, in addition to the sources such as domestic wastewaters, septic tank leakages, etc. (Subba Rao et al. 2017a).

The calcium concentrations range from 16 to $112 \mathrm{mg} / \mathrm{l}$. The village Sitarampuram is having the minimum calcium concentration of $16 \mathrm{mg} / \mathrm{l}$, while the village Bachodu is having the maximum calcium concentration of $112 \mathrm{mg} / \mathrm{l}$. For calcium, the standard deviation, mean and variance are $25.77,45.81 \mathrm{mg} / \mathrm{l}$ and $664(\mathrm{mg} / \mathrm{l})^{2}$, respectively. The magnesium concentrations range from 15 to $165 \mathrm{mg} / \mathrm{l}$. The minimum magnesium of $15 \mathrm{mg} / \mathrm{l}$ is found at Madiripuram village, while the maximum magnesium of $165 \mathrm{mg} / \mathrm{l}$ is found at Mekalthanda village. For magnesium, the standard deviation, mean and variance are 42.57, $78.90 \mathrm{mg} / 11812(\mathrm{mg} / \mathrm{l})^{2}$, respectively.

Table 4 Total hardness classification of groundwater quality (Prakash and Somashekar 2006).

\begin{tabular}{llll}
\hline S. No & $\begin{array}{l}\text { Classification of } \\
\text { Groundwater }\end{array}$ & Range in $(\mathrm{mg} / \mathrm{l})$ & $\begin{array}{l}\text { Number of sam- } \\
\text { ples of the study } \\
\text { area }\end{array}$ \\
\hline 1 & Soft & $0-75$ & - \\
2 & Moderately hard & $75-150$ & - \\
3 & Hard & $150-300$ & 6 \\
4 & Very hard & $>300$ & 16 \\
\hline
\end{tabular}


Fig. 9 Integrated groundwater quality map of the Subledu Basin for drinking purposes

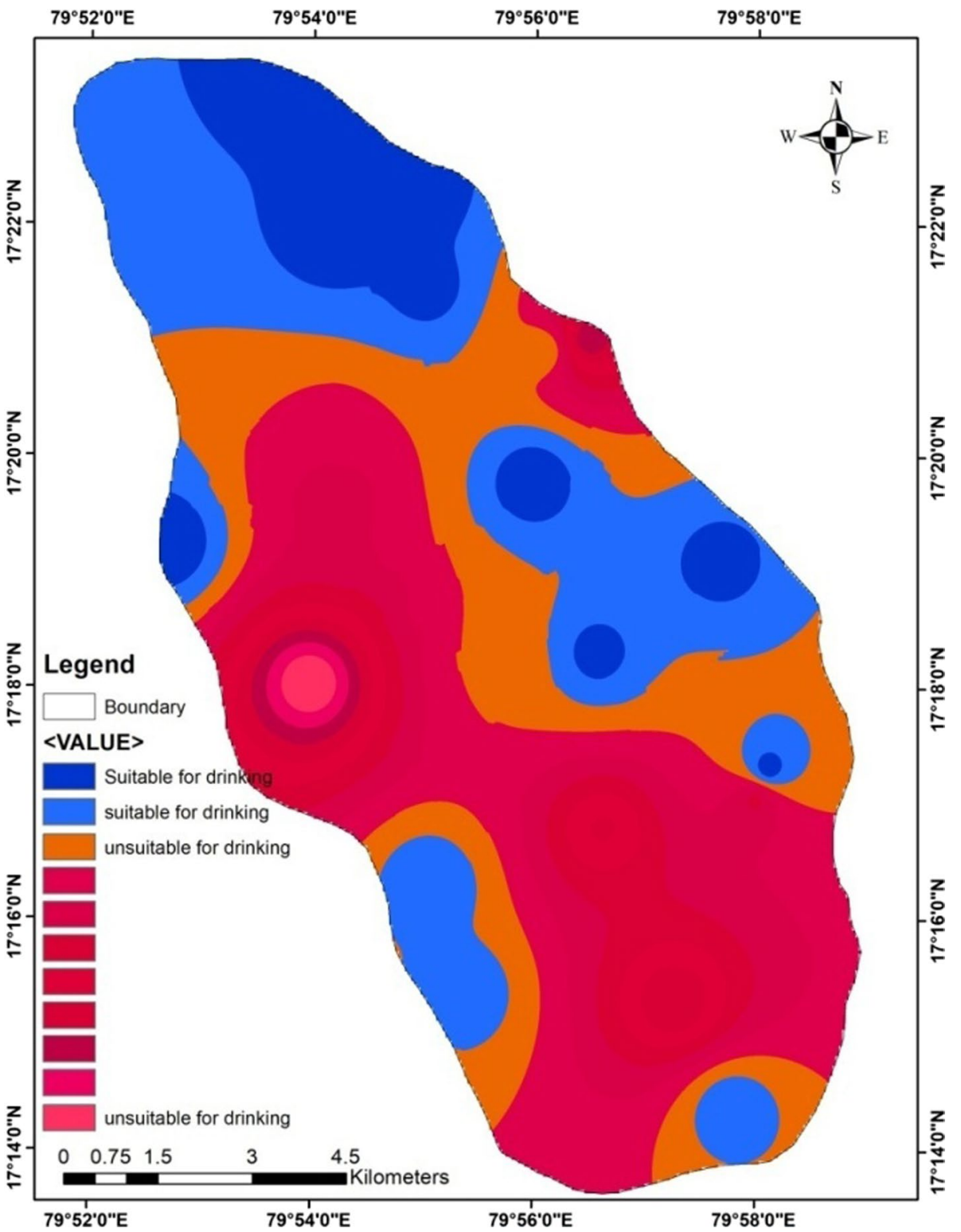

Table 5 Irrigation water quality classification based on SAR (Todd 1980).

\begin{tabular}{llll}
\hline Level & SAR & Remark on quality & $\begin{array}{l}\text { No. of } \\
\text { sam- } \\
\text { ples }\end{array}$ \\
\hline S1 & $0-10$ & Excellent & 22 \\
S2 & $10-18$ & Good & - \\
S3 & $18-26$ & Doubtful & - \\
S4 & Above 26 & Unsuitable & - \\
\hline
\end{tabular}

The hardness of water is sum of the polyvalent cations dissolved in it. The dominant cations are calcium and magnesium. The calcium carbonate $\left(\mathrm{CaCO}_{3}\right)$ hardness is termed as hardness of the water. According to US Department of Interior and the Water Quality Association, the total hardness can be classified as shown in Table 4 .

In the study area, total hardness values range from 200 to $820 \mathrm{mg} / \mathrm{l}$. The minimum total hardness of $200 \mathrm{mg} / \mathrm{l}$ is found at Madiripuram village, and the maximum total hardness of $820 \mathrm{mg} / \mathrm{l}$ is found at Bachodu Village. The total hardness has exceeded the limits of Bureau of Indian Standards at four villages. In the present study, all the groundwater samples are in hard to very hard category. From Table 4, we can say that Subledu Basin is facing a problem with very hard water. Standard deviation, mean and variance of the total hardness are $164.53 \mathrm{mg} / \mathrm{l}, 439.09 \mathrm{mg} / \mathrm{l}$ and 27,071 (mg/l) ${ }^{2}$, respectively. 
Fig. 10 Groundwater quality classification in the Subledu Basin using US salinity diagram

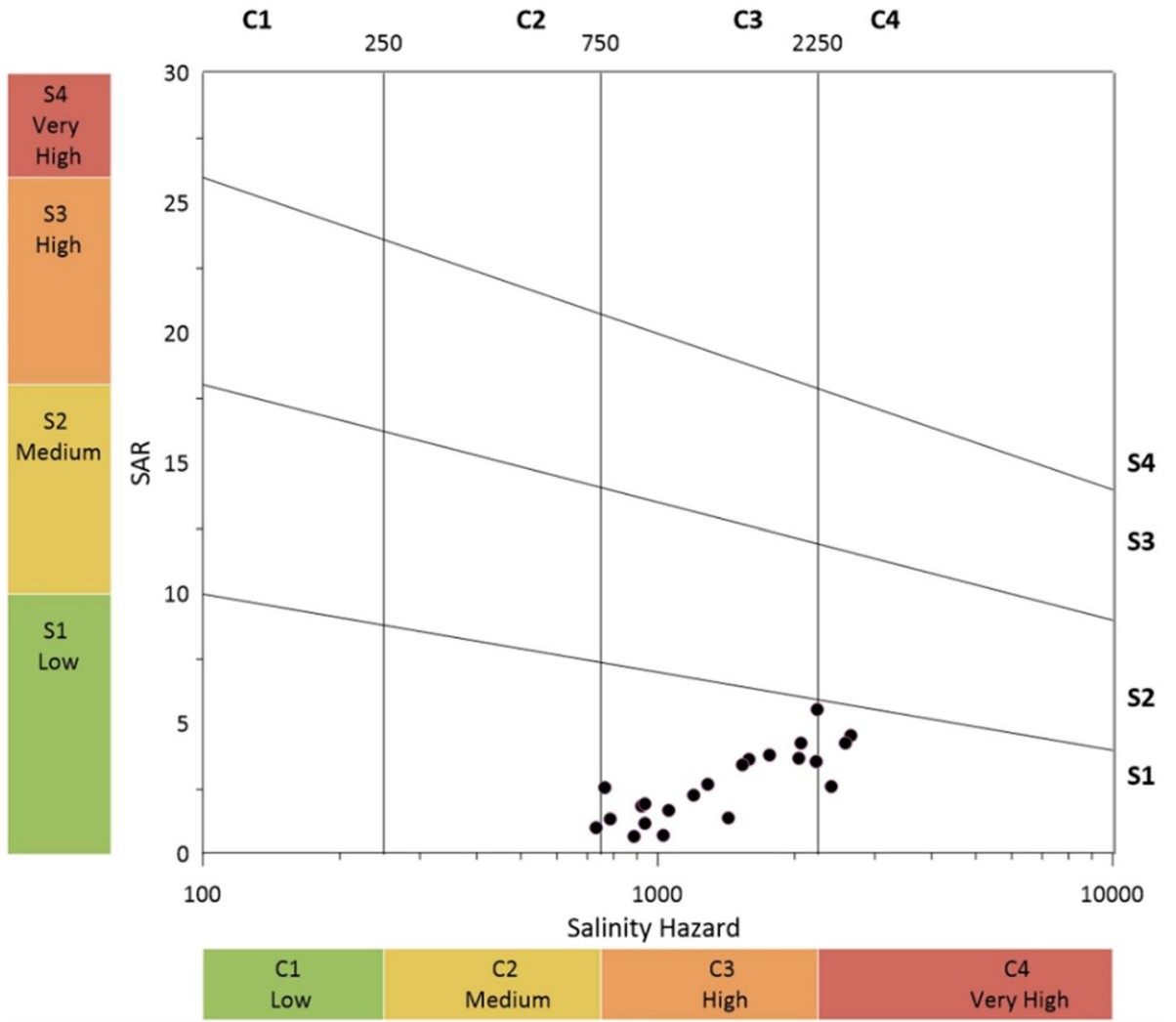

Table 6 Classification of irrigation water based on salinity (EC) (Richards 1954, Ntokozo Malaza 2017).

\begin{tabular}{lllc}
\hline Salinity & Class EC $(\mu \mathrm{S} / \mathrm{cm})$ & Quality category & $\begin{array}{l}\text { No. of } \\
\text { samples }\end{array}$ \\
\hline C1 & $<250$ & Excellent & 0 \\
C2 & $250-750$ & Good & 1 \\
C3 & $750-2250$ & permissible & 18 \\
C4 & $>2250$ & Not permissible & 3 \\
\hline
\end{tabular}

\section{Sodium and potassium}

According to Subba Rao et al. (2017a, 2019a), the primary sources of $\mathrm{Na}^{+}$are due to weathering of the plagioclase feldspars. Higher $\mathrm{Na}^{+}$content reflects the secondary source, which is a result of influence of anthropogenic sources like household wastewaters, leakage of septic tanks and irrigation practice.

The sodium concentrations vary from 30 to $287 \mathrm{mg} / \mathrm{l}$ and the minimum value is found in the village Maripeda and the maximum value is observed at Maripeda Bunglow. In the present study, highest concentration of potassium is $366 \mathrm{mg} / \mathrm{l}$ and it is found at Hasnabad and the minimum value is $2 \mathrm{mg} / \mathrm{l}$ and is found at Maripeda, Pocharam and Eluvarigudem villages. Due to high consumption of potassium, organs
Table 7 Classification of irrigation water based on sodium percentage (Wilcox 1955).

\begin{tabular}{lll}
\hline Groundwater class & Sodium percentage & $\begin{array}{l}\text { No. of } \\
\text { sam- } \\
\text { ples }\end{array}$ \\
\hline Excellent & $<20$ & 2 \\
Good & $20-40$ & 9 \\
Permissible & $40-60$ & 10 \\
Doubtful & $60-80$ & 1 \\
Unsuitable & $>80$ & - \\
\hline
\end{tabular}

such as kidneys and heart may not function properly. The standard deviation, mean and variance of the sodium are $79.66 \mathrm{mg} / \mathrm{l}, 131.81 \mathrm{mg} / \mathrm{l}$ and $6347\left(\mathrm{mg} / \mathrm{l}^{2}\right.$, respectively, and for the potassium the standard, mean and variance values are $75.30 \mathrm{mg} / \mathrm{l}, 26.36 \mathrm{mg} / \mathrm{l}$ and $5671(\mathrm{mg} / \mathrm{l})^{2}$, respectively. Five samples in the case of sodium and one sample in the case of potassium have exceeded the permissible limit.

\section{Sulfate and phosphate}

Sulfate is generally found in natural water due to discharges from domestic sewage, effluents released from the industries and emissions from automobiles. The sulfate concentrations range from $9 \mathrm{mg} / \mathrm{l}$ at Hasnabad village to $51 \mathrm{mg} / \mathrm{l}$ at Narasimhulagudem village. In the present analysis of 
groundwater samples, all the sulfate values are below the permissible limit of BIS; hence, there is no problem with the sulfate. The sulfate's standard deviation, mean and variance are $13.12 \mathrm{mg} / \mathrm{l}, 25.36 \mathrm{mg} / \mathrm{l}$ and $172.23(\mathrm{mg} / \mathrm{l})^{2}$, respectively.

As per WHO, the permissible value of phosphate concentration in the groundwater is $0.1 \mathrm{mg} / \mathrm{l}$. Since no BIS standards exist for phosphate in India, according to Rajmohan and Elango (2005), the soils holding capacity of phosphate is low when it is less soluble. The maximum value of phosphate is found to be $0.42 \mathrm{mg} / \mathrm{l}$ at Hasnabad village, and the minimum value is found to be $0.04 \mathrm{mg} / \mathrm{l}$ at Tallacheruvu; only one sample is exceeding the permissible limit.

\section{Integrated groundwater quality map for drinking water purposes}

Figure 9 shows the integrated map of groundwater quality, and it is prepared using the IDW tool in ArcGIS 10.2 software. This map shows the parts of study area where the groundwater is suitable and not suitable for drinking purposes. It is prepared based on nitrate, fluoride, total hardness, total dissolved solids and chloride. Cool to hot colors indicate degree of suitability of groundwater for drinking purposes. Dark-blue color and light-blue color areas are suitable for drinking purposes, while all other areas are not suitable for drinking purposes. In the southern and western parts of the basin as well as few parts in the middle of the basin, the groundwater quality is poor compared to north, east and few parts in the west, south and eastern boundaries of the study area.

\section{Suitability of groundwater for irrigation}

According to Wagh et al. (2019) and Deepali et al. (2020a), the groundwater quality used for irrigation purposes plays an important role for growth and production of the crop. Physical properties such as soil permeability are very sensitive to type of exchangeable ions. By using salinity and sodium hazards, the suitability of groundwater for irrigation can be determined (Subba Rao 2008; Chen et al. 2019; Karunanidhi et al. 2020a, b). The crop yields depends on Salinity hazard, and it can reduce the crop yield due to excess of salt

Table 8 Classification of irrigation water based on residual sodium carbonate (Eaton 1950; Wilcox et al. 1954).

\begin{tabular}{llc}
\hline RSC & Water quality & $\begin{array}{l}\text { No. of } \\
\text { sam- } \\
\text { ples }\end{array}$ \\
\hline$<1.25$ & Good & 17 \\
$1.25-2.50$ & Doubtful & 3 \\
$>2.50$ & Unsuitable & 2 \\
\hline
\end{tabular}

content in the groundwater. Similarly, the sodium hazard can also affect the soil permeability and reduce the infiltration rates of water and air into soil structure (Aravinthasamy et al. 2020). If the salinity and sodium hazards are greater, the higher is the risk of suitability of groundwater quality for irrigation purpose (Subba Rao 2017; Tolera et al. 2020).

\section{Sodium adsorption ratio (SAR)}

The permeability and infiltration rates decrease due to high levels of sodium concentrations. The sodium concentration can also effect the less sensitive crops (Zaman et al. 2018; Sarath Prasanth et al. 2012). With reference to SAR (Todd 1980), the irrigation water can be classified as presented in Table 5. According to Todd classification, almost all the samples in the study area are of excellent quality for irrigation.

The SAR values are changing from 0.68 to 5.58 (Table 3 ). With the usage of water of high SAR values continuously for irrigation, there will be breakdown in the soil structure physically (Nagarajan et al. 2009). The standard deviation, mean and variance of the SAR are 1.35, 2.67 and 1.82, respectively. By using the SAR and specific conductivity, we can draw the US Salinity Laboratory (USSL) diagram (Fig. 10).

\section{Irrigation water quality based on salinity}

Classification of irrigation water based on salinity is shown in Table 6 for the groundwater of the study area. Only three samples were not in permissible category. All other 19 samples were suitable for irrigation.

For irrigation water classification, US Salinity Laboratory (Richards 1954) diagram is also used in the Subledu Basin. In order to ensure the groundwater quality for irrigation purpose, United States Soil Salinity Laboratory staff (USSLS) diagram can be used (Subba Rao 2017; Wagh et al. 2018; Deepali et al. 2020a). The graph (Fig. 10 ) is drawn by taking the SAR on Y- axis and the specific electrical conductance on $\mathrm{X}$ - axis. According to Hem (1985), this diagram is used for finding the salinity problems and exchange of ions. Based on the salinity hazard, it is divided into four groups, low (C1), medium (C2), high (C3), and very high (C4), and it is shown in Table 6. In the same way, sodium alkali hazard is also divided into low (S1), medium (S2), high (S3) and very high (S4). In the present study area, maximum groundwater samples fall under the C3S1 category indicating that the values are in the high salinity and low alkali hazard range, and it is shown in Fig. 10. It means that there is no sodium hazard but salinity hazard is present. 
Fig. 11 Distribution of magnesium hazard in the Subledu Basin

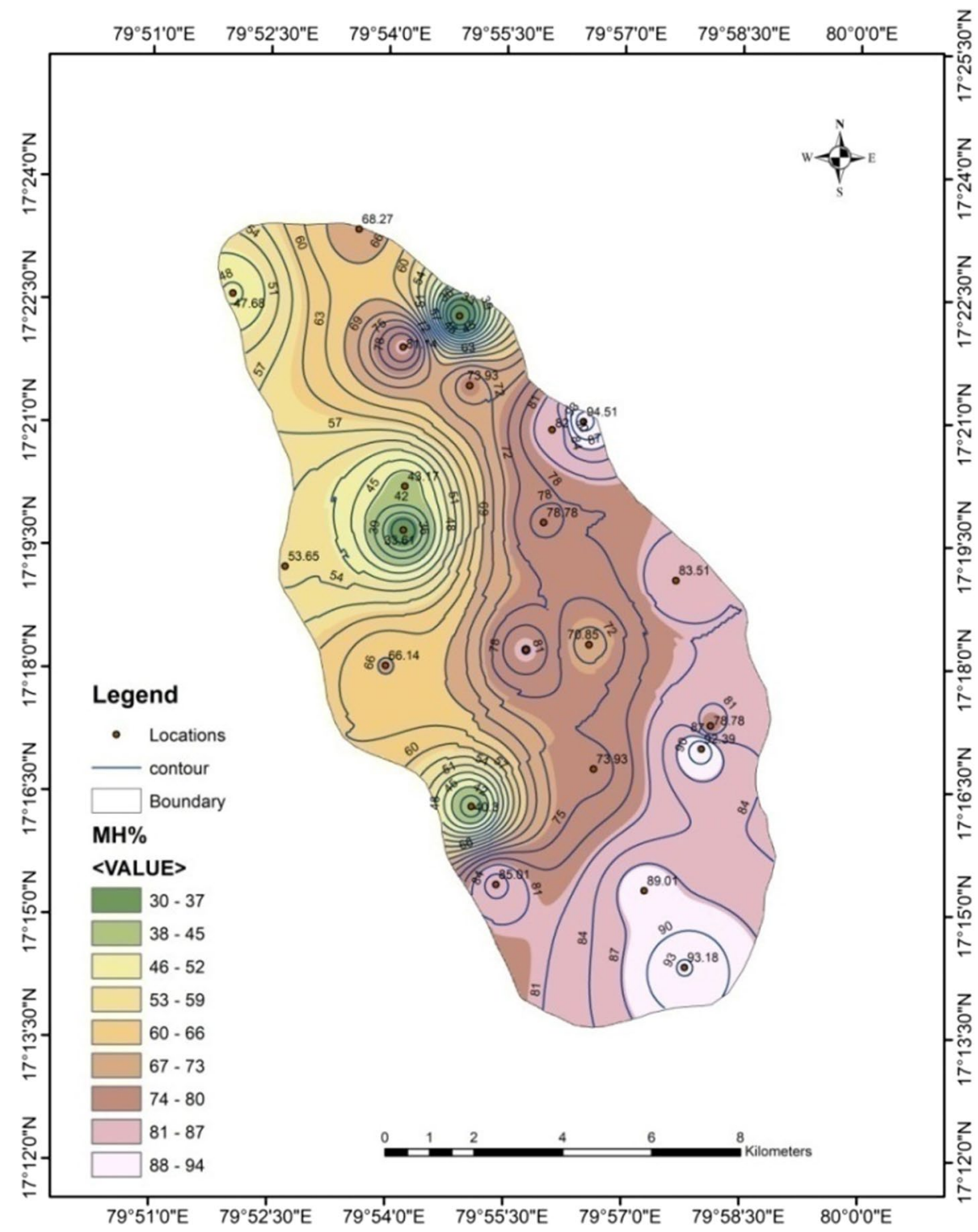

\section{Sodium percentage (SP)}

In order to estimate the sodium hazard in irrigation water, we use the sodium percentage. Based on sodium percentage, only one groundwater sample is doubtful. Ten groundwater samples are within permissible limits, nine samples are good and two samples are excellent. The standard deviation, mean and variance of the sodium percentage are 13.62, 38.87 and 185 , respectively. Based on sodium percentage, the classification of groundwater samples is shown in Table. 7.

\section{Residual sodium carbonate (RSC) index}

The high-concentrated bicarbonate and carbonate ions accompanied with alkaline earths are the possible cause of precipitation of $\mathrm{Ca}$ and $\mathrm{Mg}$ (Raghunath 2000). The residual sodium carbonate equals to the sum of carbonates and bicarbonate concentrations minus calcium and magnesium concentrations. The standard deviation, mean and variance of residual sodium carbonate are $3.15 \mathrm{mg} / 1,0.7 \mathrm{mg} / \mathrm{l}$ and 9.96 $(\mathrm{mg} / \mathrm{l})^{2}$, respectively.

Residual sodium carbonate values range from 10.07 to $6.07 \mathrm{meq} / \mathrm{l}$. Table 8 shows the irrigation water classification of groundwater in the study area based on RSC values. According to the this classification, we can say that 17 groundwater samples are having no hazard and three groundwater samples are in medium hazard and two are in high hazard for irrigation. The US Department of Agriculture stated that the water having RSC value more than $2.5 \mathrm{meq} / \mathrm{l}$ is not suitable for irrigation purposes (Ntokozo Malaza 2017). 


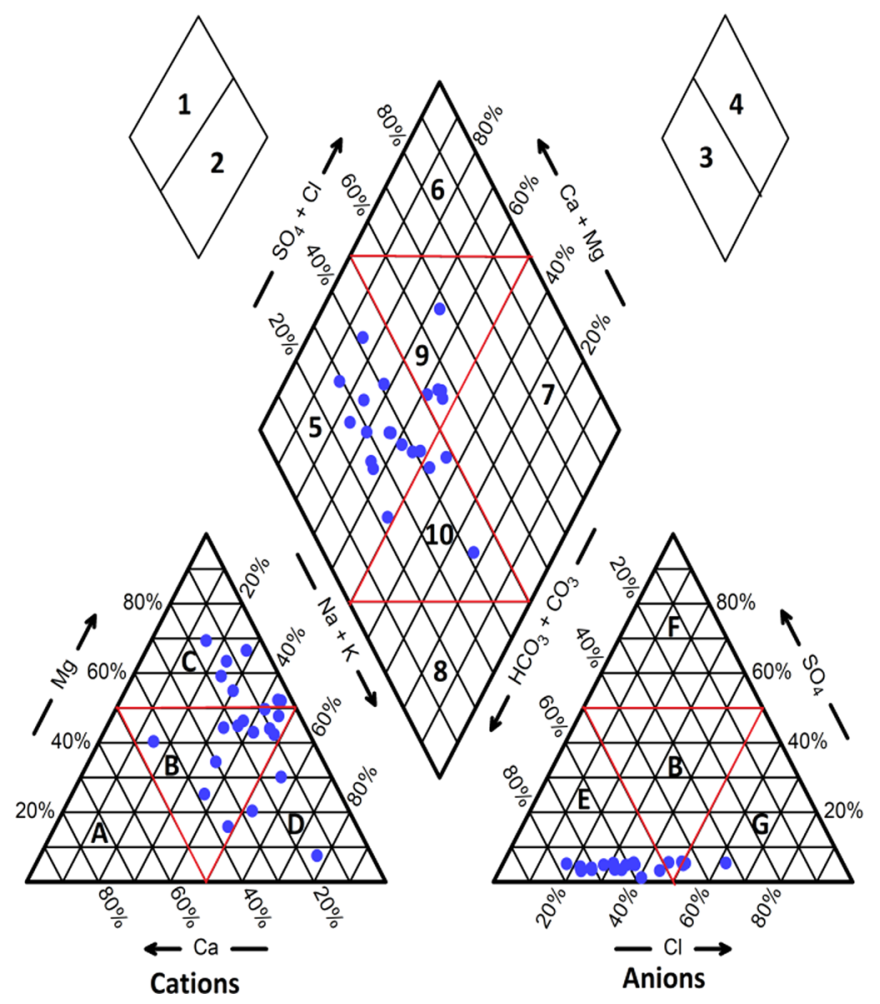

Fig. 12 Piper's trilinear classification of groundwater in the Subledu Basin
Legend

A- Calcium Type

B-No dominent Type

C-Megnesium Type

D-Sodium and Potassium Type

E-Bicarbonate Type

F-Sulphate Type

G-Chloride Type

1-Alkaline earths exceed alkalies

2-Alkalies exceed alkaline earths

3-Weak acids exceed strong acids

4-Strong acids exceed weak acids

5-Carbonate hardness (Secondary alkalinity) exceed 50 percent.

6-Non carbonate hardness (Secondary Salinity) exceeds 50 percent

7-Non carbonate alkali (Primary Salinity) exceeds 50 percent

8-Carbonate alkali (Primary alkalinity) exceed 50 percent.

9 -Non of the cation or anoin pair exceeds 50 percent.

Calcium chloride Type

10 -Non of the cation or anoin pair exceeds 50 percent.

Calcium chloride Type
Table 9 Classification of groundwater quality based on Kelley's ratio (Kelley 1963).

\begin{tabular}{llllr}
\hline $\begin{array}{l}\text { S. No } \\
\text { water }\end{array}$ & $\begin{array}{l}\text { Quality of } \\
\text { ues of Kelley's } \\
\text { ratio }\end{array}$ & $\begin{array}{l}\text { No. of samples } \\
\text { (Out of total } \\
\text { 22 samples) }\end{array}$ & Percentage \\
\hline 1 & Safe & $<1$ & 20 & 90.90 \\
2 & Unsafe & $>1$ & 2 & 9.10 \\
\hline
\end{tabular}

\section{Magnesium hazard (MH)}

The crop yield can be decreased due to the presence of magnesium in groundwater (Gowd 2005). If the magnesium hazard value is greater than $50 \%$, then the water is not suitable for irrigation (Siva Prasad and Venkateswara Rao 2018). Magnesium hazard values in the study area range from $30.27 \%$ to $94.51 \%$. Only five samples are less than $50 \%$, and rest of the samples have exceeded the $50 \%$. According to magnesium hazard, only $22.72 \%$ of groundwater in the study area is suitable for irrigation and the rest $77.28 \%$ is not suitable. The standard deviation, mean and variance of the magnesium hazard are 19.39, 70.05 and 376, respectively.

From Fig. 11, it can be observed that the magnesium hazard is more at southern and eastern parts of the basin compared to northern and western parts.

\section{Piper's trilinear classification}

In the Piper's trilinear diagram (Piper 1944), it is having two triangles as shown in Fig. 12, one is used for plotting cations and another is used for plotting anions (Fig. 12). The resultant of the combination of the two triangles can be expressed in the shape of a diamond field.

Figure 12 shows the Piper's trilinear classification of the 22 groundwater samples of the study area. From Fig. 12, we can say that most of the samples, i.e., 16 samples, are in the area No.5. From the legend, we can infer that this area shows the carbonate hardness (secondary alkalinity) exceeds 50 percent. The remaining groundwater samples, i.e., six samples, are in the area No.9, indicating that it is the neutral water. Therefore, the secondary alkalinity is the dominant hydrochemical facies of groundwater in the study area.

\section{Kelley's ratio}

Kelley et al. (1940) stated that the high presence of sodium in the irrigation water causes the retardation of plant's growth. It is expressed as Kelley's ratio and if the ratio is less than 1, the groundwater quality is safe for irrigation. If it is greater than 1 , then it is not safe for irrigation. In the present study area, the Kelley's ratio is varying from 0.16 
Fig. 13 Groundwater quality map of the Subledu Basin for irrigation purposes

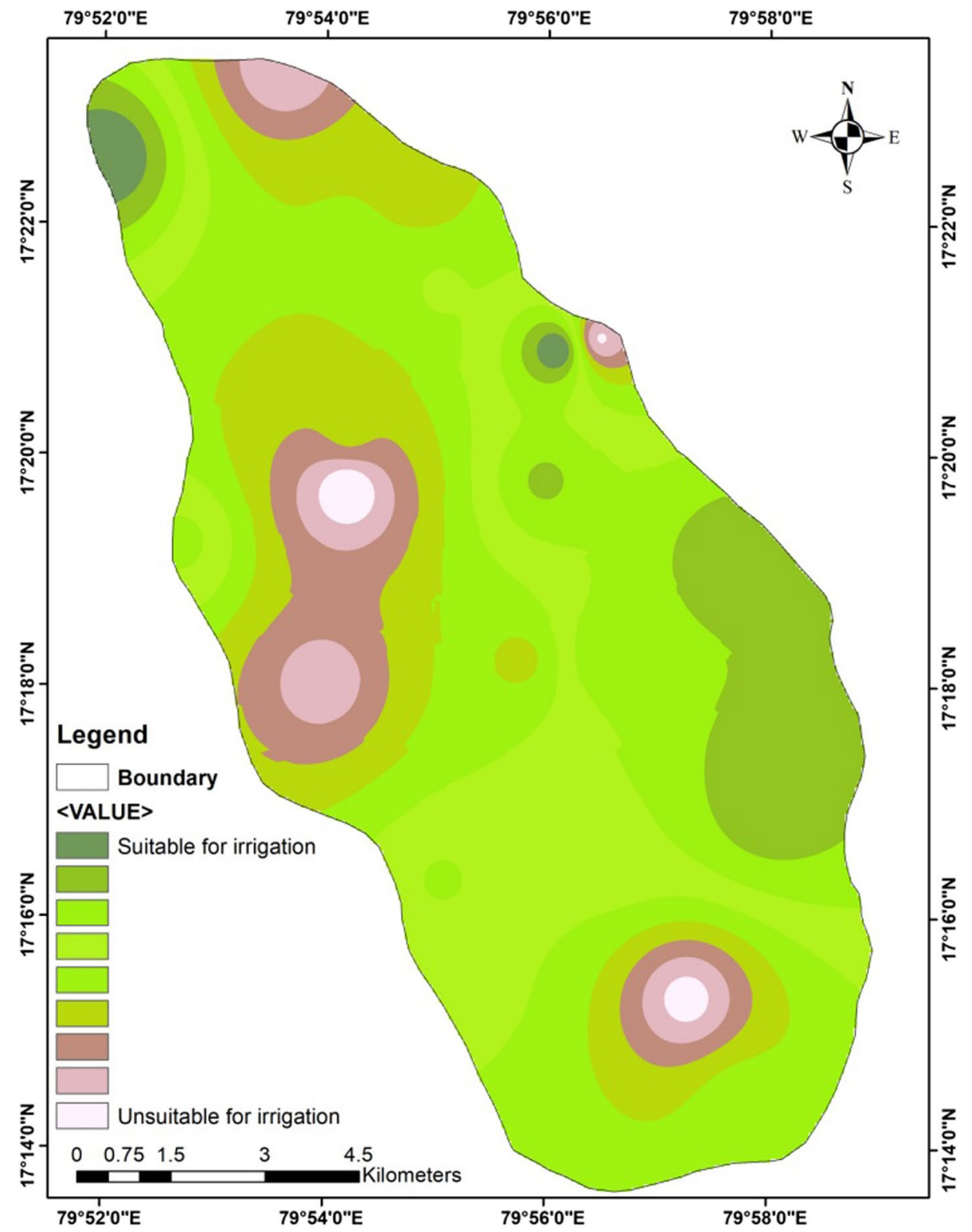

to 1.37. The standard deviation, mean and variance of the Kelley's ratio are $0.31,0.63$ and 0.09 , respectively.

In the study area, out of 22 groundwater samples 20 samples are in safe range for irrigation and two groundwater samples have exceeded Kelley's ratio; they are Maripeda Bunglow and Hasnabad. Based on Kelley's ratio, the groundwater samples are classified in Table 9.

\section{Integrated groundwater quality map for irrigation}

Figure 13 shows the suitability of groundwater for irrigation. In this map, residual sodium carbonate, EC and Kelley's ratio are integrated and the map is prepared. For irrigation purpose, the groundwater is unsuitable at few places in the western middle parts of the basin as well as north and southern tips of the basin as shown in Fig. 13. The large rest of the basin is suitable for irrigation.

\section{Conclusions}

Twenty-two groundwater samples were analyzed in the Subledu Basin for chemical composition and their suitability for irrigation and drinking purposes. The fluoride concentrations have exceeded the BIS standards at three places and nitrate concentration at 12 villages; therefore, totally 13 groundwater samples are not suitable for drinking purpose. The integrated groundwater quality map for drinking purposes shows that in the large parts of southern and western parts of the basin as well as in the middle of the basin, the groundwater is not suitable for drinking. 
For irrigation purpose, Kelley's ratio is more than 1 at two villages only. According to USSL salinity diagram, we can conclude that maximum groundwater samples fall under the $\mathrm{C} 3 \mathrm{~S} 1$ category that means the samples are having high salinity and low alkali hazard range. The cation dominance order is, $\mathrm{K}^{+}>\mathrm{Na}^{+}>\mathrm{Mg}^{+2}>\mathrm{Ca}^{+2}$. Similarly, for anions the order of dominance is $\mathrm{HCO}^{-}>\mathrm{NO}_{3}^{-}>\mathrm{Cl}^{-}>\mathrm{SO}_{4}^{-2}>\mathrm{CO}^{-2}>\mathrm{F}^{-}>\mathrm{O}-\mathrm{PO}_{4}^{-3}$. In the case of TDS except two, all the groundwater samples are having high TDS concentration and exceeded the BIS desirable limit. Based on total hardness results, all the groundwater samples in the basin are very hard water. From the Piper's trilinear diagram, the secondary alkalinity is the dominant hydrochemical facies of groundwater in the study area. The integrated groundwater quality map for irrigation shows that the groundwater is suitable for irrigation except in few packets of western middle parts of the basin as well as north and southern tips of the basin.

Authors' contributions All authors contributed to this paper.

Funding The author(s) received no specific funding for this work.

Data availability All the groundwater samples were collected by us, and required materials were used for processing.

\section{Declaration}

Conflict of interest The authors declared that they have no conflict of interest.

Ethics approval The research in this paper does not involve human participants and/or animals.

\section{Consent to participate Yes.}

Consent for publication Yes

Open Access This article is licensed under a Creative Commons Attribution 4.0 International License, which permits use, sharing, adaptation, distribution and reproduction in any medium or format, as long as you give appropriate credit to the original author(s) and the source, provide a link to the Creative Commons licence, and indicate if changes were made. The images or other third party material in this article are included in the article's Creative Commons licence, unless indicated otherwise in a credit line to the material. If material is not included in the article's Creative Commons licence and your intended use is not permitted by statutory regulation or exceeds the permitted use, you will need to obtain permission directly from the copyright holder. To view a copy of this licence, visit http://creativecommons.org/licenses/by/4.0/.

\section{References}

Adimalla N, Taloor AK (2020) Hydrogeochemical investigation of groundwater quality in the hard rock terrain of South India using
Geographic Information System (GIS) and groundwater quality index (GWQI) techniques. Groundw Sustain Develop. https://doi. org/10.1016/j.gsd.2019.100288

Ahada CPS, Suthar S (2017) Assessment of human health risk associated with high groundwater fluoride intake in southern districts of Punjab, India. Expos Health 11:267-275. https://doi.org/10. 1007/s12403-017-0268-4

Alekhya K, Ramadas G, Vidyasaga D (2018) Groundwater quality assessment in jagtial district telangana state-a case study. SSRG Int J Agric Environ Sci (SSRG-IJAES) 5(5):1-14

Ali SA, Ali U (2018) Hydrochemical characteristics and spatial analysis of groundwater quality in parts of Bundelkhand massif. India Appl Water Sci 8(1):1-15. https://doi.org/10.1007/s13201-018-0678-x

American Public Health Association (APHA) (1998) Standard methods for the examination of water and wastewater 20. United Book Press Inc, Baltimore

Aravinthasamy P, Karunanidhi D, Subba Rao N, Subramani T, Srinivasamoorthy $K$ (2020) Irrigation risk assessment of groundwater in a non-perennial river basin of South India: implication from irrigation water quality index (IWQI) and geographical information system (GIS) approaches. Arab J Geosci. https://doi.org/10. 1007/s12517-020-06103-1

Arshad S, Ashwin Kumar PSS, Rajani D, Sukumaran MK (2015) A study on fluoride in borewell water of Nalgonda district Telangana, India. Int J Curr Microb Appl Sci 4:323-328

Biswas A, Bhattacharya P, Mukherjee A, Nath B, Alexanderson H, Kundu AK, Chatterjee D, Jacks G (2014) Shallow hydrostratigraphy in an arsenic affected region of Bengal Basin: implication for targeting safe aquifers for drinking water supply. Sci Total Environ 485:12-22

Bureau of Indian Standards (BIS) (2012) Guidelines for Drinking-water Quality, Indian Standard (IS: 10500), New Delhi India

Central Groundwater Board (CGWB), (2005) District groundwater management studies of Palghat District, Kerala, Technical Report Series Report No.25/KR/CGWB/2004-05

Chen J, Huang Q, Lin Y, Fang Y, Qian H, Liu R, Ma H (2019) Hydrogeochemical characteristics and quality assessment of groundwater in an irrigated region. Northwest China Water 11:96. https:// doi.org/10.3390/w11010096

Deepali M, Malpe DB, Karunanidhi D, Patil PD, Li P (2020) Hydrogeochemical evaluation, suitability, and health risk assessment of groundwater in the watershed of Godavari basin, Maharashtra, Central India. Environ Sci Poll Res. https://doi.org/10.1007/ s11356-020-10032-7

Eaton FM (1950) Significance of carbonates in irrigation waters. Soil Sci 69:123-133

Eskiocak S, Dundar C, Basoglu T, Altaner S (2005) The effects of taking chronic nitrate by drinking water on thyroid functions and morphology. Clin Exp Med 5:66-71. https://doi.org/10.1007/ s10238-005-0068-1

Gowd SS (2005) Assessment of groundwater quality for drinking and irrigation purpose: a case study of Pedavanka Watershed, Anantapur District, Andhra Pradesh, India. Environ Geol 48:702-712

He S, Wu J (2019) Hydrogeochemical characteristics, groundwater quality and health risks from hexavalent chromium and nitrate in groundwater of Huanhe Formation in Wuqi County, northwest China. Expos Health 11:125-137. https://doi.org/10.1007/ s12403-018-0289-7

He X, Wu J, He S (2019) Hydrochemical characteristics and quality evaluation of groundwater in terms of health risks in Luohe aquifer in Wuqi County of the Chinese Loess Plateau, northwest China. Hum Ecol Risk Assess Int J 25(1-2):32-51. https://doi. org/10.1080/10807039.2018.1531693

Hem JD (1985) Study and interpretation of the chemical characteristics of natural water. USGS Water Supply Paper 2254:117-120

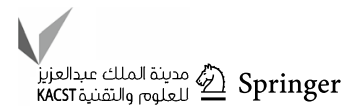


Hilbert LR, Jellesen MS, Rasmussen AA (2006) (2006) A review of metal release in the food industry. Mater Corros 57(5):387-393. https://doi.org/10.1002/maco.200503953

Ibrahim AK, Gadam AU, Usman A, Umar AH (2015) Suitability assessment of groundwater for drinking and irrigation use. J Agric Vet Sci 8:25-32. https://doi.org/10.9790/2380-08412532

Jasrotia AS, Taloor AK, Andotra U, Bhagat BD (2018) Geoinformatics based groundwater quality assessment for domestic and irrigation uses of the Western Doon valley, Uttarakhand, India. Groundw Sustain Develop 6:200-212

Jasrotia AS, Taloor AK, Andotra U, Kumar R (2019) Monitoring and assessment of groundwater quality and its suitability for domestic and agricultural use in the Cenozoic rocks of Jammu Himalaya, India: a geospatial technology based approach. Groundw Sustain Develop. https://doi.org/10.1016/j.gsd.2019.02.003

Karunanidhi D, Aravinthasamy P, Subramani T, Jianhua W, Srinivasamoorthy K (2019) Potential health risk assessment for fluoride and nitrate contamination in hard rock aquifers of Shanmuganadhi River basin South, India. Int J Hum Ecol Risk Assess. https://doi.org/10.1080/10807039.2019.1568859

Karunanidhi D, Aravinthasamy P, Priyadarsi DR, Praveenkumar RM, Prasanth K, Selvapraveen S et al (2020a) Evaluation of noncarcinogenic risks due to fluoride and nitrate contaminations in a groundwater of an urban part (Coimbatore region) of south India. Environ Monit Assess 192:102. https://doi.org/10.1007/ s10661-019-8059-y

Karunanidhi D, Aravinthasamy P, Deepali M, Subramani T, Bellows CB, Li P (2020b) Groundwater quality evolution based on geochemical modeling and aptness testing for ingestion using entropy water quality and total hazard indexes in an urbanindustrial area (Tiruppur) of Southern India. Environ Sci Pollut Res. https://doi.org/10.1007/s11356-020-10724-0

Kelley WP (1963) Use of saline irrigation. Water Soil Sci 95(4):355-391

Kelley WP, Brown SM, Leibig GI (1940) Chemical effects of saline irrigation water on soils. Soil Sci 49:95-107

Kumar SK, Chandrasekar N, Seralathan P, PrinceS G, Magesh NS (2011) Hydrogeochemical study of shallow carbonate aquifers, Rameshwaram Island, India. Environ Monit Assess. https://doi. org/10.1007/s10661-011-2249-6

Li P, Li X, Meng X, Li M, Zhang Y (2016) Appraising groundwater quality and health risks from contamination in a semi-arid region of Northwest China. Expos Health 8(3):361-379. https:// doi.org/10.1007/s12403-016-0205-y

Magesh NS, Chandrasekar N (2011) Evaluation of spatial variations in groundwater quality by WQI and GIS technique: a case study of Virudunagar District, Tamil Nadu, India. Arab J Geosci. https://doi.org/10.1007/s12517-011-0496-Z

Malaza N (2017) Hydrogeochemical assessment of groundwater quality in the Soutpansberg Basin around Tshikondeni Limpopo Province, South Africa. Geochem: Explor Environ Anal 17:35-41. https://doi.org/10.1144/geochem2016-433

Malcolm J, Michael Johnson K, Andrew J, Ratnayaka DD (2017) Chemistry, microbiology and biology of water. Twort's water supply. Elsevier, London, pp 235-321

Mills B (2003) Interpreting water analysis for crop and pasture. File no. FS0334, DPI's Agency for Food and Fiber Sciences, Toowoomba

Mitchell and Stapp (1992) Field Manual for Water Quality Monitoring

Moharir K, Pande C, Patil S (2017) Inverse modeling of aquifer parameters in basaltic rock with the help of pumping test method using MODFLOW software. Geosci Front Elsevier J 8:1-13

MPCA (2019) Chloride and fluoride in Minnesota's groundwater. Minnesota Pollution Control Agency. Environmental Outcomes Division, Ground Water Monitoring \& Assessment Program. United States
Nagarajan et al. (2009) Chapter 5 Irrigational suitability of groundwater accessed from web source on May 20, 2020

Nishanthiny SC, Thushyanthy M, Barathithasan T, Saravanan S (2010) Irrigation water quality based on hydro chemical analysis, Jafna, Sri Lanka. American-Eurasian J Agric Environ Sci 7(1):100-102

Pande CB, Moharir K (2018) Spatial analysis of groundwater quality mapping in hard rock area in the Akola and Buldhana districts of Maharashtra, India. Appl Water Sci 8:106. https://doi.org/10. 1007/s13201-018-0754-2

Pawar NJ, Shaikh IJ (1995) Nitrate pollution of ground waters from shallow basaltic aquifers, Deccan trap Hydrologic Province, India. Environ Geol 25:197-204

Piper AM (1944) A geographic procedure in the geochemical interpretation of water analysis. Transactions American Geophysical 25:914-923

Prakash KL, Somashekar RK (2006) Groundwater quality-assessment on Anekal Taluk, Bangalore urban district, India. J Environ Biol 27(4):633-637

Prasanth Sarath SV, Magesh NS, Jitheshlal KV, Chandrasekar N, Gangadhar K (2012) Evaluation of groundwater quality and its suitability for drinking and agricultural use in the coastal stretch of Alappuzha District, Kerala, India. Appl Water Sci 2(165):175. https://doi.org/10.1007/s13201-012-0042-5

Qasemi M, Farhang M, Biglari H, Afsharnia M, Ojrati A, Khani F, Samiee M, Zarei A (2018) Health risk assessments due to nitrate levels in drinking water in villages of Azadshahr, northeastern Iran. Environ Earth Sci 77(23):1-9

Raghunath HM (2000) Ground water hydrology. Wiley, New Delhi

Rainfall data Source from Telangana State Development Planning Society, North Block, Ground floor, Ghanaka bhavan premises, Khairatabad, Hyderabad, collected on Sept., 2020.

Rajmohan N, Elango L (2005) Nutrient chemistry of groundwater in an intensively irrigated region of southern India. J Environ Geol 47:820-830

Richards LA (1954) Diagnosis and improvement of saline and alkaline soils. US Department of Agriculture hand book, US Salinity Laboratory, USA

Roy A, Keesari T, Mohokar H, Sinha UK, Bitra S (2018) Assessment of groundwater quality in hard rock aquifer of central Telangana state for drinking and agriculture purposes. Appl Water Sci 8(124):1-18. https://doi.org/10.1007/s13201-018-0761-3

Schiavo MA, Havser S, Gusimano G, Gatto L (2006) Geochemical characterization of groundwater and submarine discharge in the south-eastern Sicily. Cont Shelf Res 26(7):826-834

Singh G, Rishi MS, Arora NK (2019) Integrated GIS based modelling approach for irrigation water quality suitability zonation in parts of Satluj River Basin, Bist Doab region, North India. SN Appl Sci. https://doi.org/10.1007/s42452-019-1405-4

Siva Prasad Y, Venkateswara Rao B (2018) Monitoring and assessment of groundwater quality in a khondalitic terrain, Andhra Pradesh, India. Environ Monit Assess 190:426. https://doi.org/ 10.1007/s10661-018-6757-5

Srinivas Y, Hudson Oliver D, Stanley Raj A, Chandrasekar N (2013) Evaluation of groundwater quality in and around Nagercoil town, Tamil Nadu, India: an integrated geochemical and GIS approach. Appl Water Sci 3:631-651

Srinivasa Rao Y, Jugran DK (2003) Delineation of groundwater potential zones and zones of groundwater quality suitable for domestic purposes using remote sensing and GIS. Hydrol Sci J 48(5):821-833. https://doi.org/10.1623/hysj.48.5.821.51452

Subba Rao N (2008) Factors controlling the salinity in groundwater in parts of Guntur district, Andhra Pradesh, India. Environ Monit Assess 138:327-341. https://doi.org/10.1007/ s10661-007-9801-4

Subba Rao N (2017) Hydrogeology: problems with solutions. Prentice Hall of India, New Delhi 
Subba Rao N, Deepali M, Dinakar A, Chandana I, Sunitha B, Ravindra B et al (2017) Geochemical characteristics and controlling factors of chemical composition of groundwater in a part of Guntur district, Andhra Pradesh, India. Environ Earth Sci 76:747. https://doi.org/10.1007/s12665-017-7093-8

Subba Rao N, Srihari CH, Deepthi Spandana B, Sravanthi M, Kamalesh T, Abraham Jayadeep V (2019) Comprehensive understanding of groundwater quality and hydrogeochemistry for the sustainable development of suburban area of Visakhapatnam, Andhra Pradesh, India. Int J Hum Ecol Risk Assess. https://doi. org/10.1080/10807039.2019.1571403

Subramani T, Elango L, Damodarasamy SR (2005) Groundwater quality and its suitability for drinking and agricultural use in Chithar River Basin, Tamil Nadu, India. Environ Geol 47:1099-1110

Sujatha D, Reddy RB (2003) Quality characterization of groundwater in the south eastern parts of the Ranga Reddy district, Andhra Pradesh, India. Environ Geol 44(5):570-576

Sunitha V (2013) Nitrates in groundwater: health hazards and remedial measures. Indian J Adv Chem Sci 1(3):164-170

Szabolcs I, Darab C (1964) The influence of irrigation water of high sodium carbonate content of soils. In: Proceedings of 8th ISSS. Transactions 2: 802-812

Todd DK (1980) Groundwater Hydrology. Wiley, New York

Tolera MB, Choi H, Chang SW, Chung M (2020) Groundwater quality evaluation for different uses in the lower Ketar Watershed, Ethiopia. Environ Geochem Health 2:3059-3078. https://doi.org/ 10.1007/s10653-019-00508-y

Vijaya Lakshmi D, Jeevan Rao K, Ramprakash T, Reddy PK (2016) Assessment of Fluoride in Groundwater for Drinking and Agriculture purposes in Ramannapet Mandal of Nagonda Dist, Telangana, India. J Pharm, Chem Biol Sci 4(2):169-175

Vodela JK, Renden JA, Lenz SD, Mc Elhenney WH, Kemppainen BW (1997) Drinking water contaminants (arsenic, cadmium, lead, benzene and trichloroethylene). Interaction of contaminants with nutritional status on general performance and immune function in broiler chickens. Poult Sci 76:1474-1492
Wagh VM, Panaskar DB, Aamalawar M, Lolage Y, Mukate SV, Admilla N (2018) Hydrochemical characterisation and groundwater suitability for drinking and irrigation uses in semiarid region of Nashik Maharashtra India. Hydrospatial Anal 2:43-60. https:// doi.org/10.21523/gcj3.18020104

Wagh VM, Panaskar DB, Jacobs JA, Mukate SV, Muley AA, Kadam AK (2019) Influence of hydrogeochemical processes on groundwater quality through geostatistical techniques in Kadava River basin, Western India. Arab J Geosci. https://doi.org/10.1007/ s12517-018-4136-8

Walton WC (1970) Groundwater resources evaluation. Mc Graw Hill Book Co, New York

Wilcox LV (1955) Classification and use of irrigation waters. US Department of Agriculture, Washington

Wilcox LV, Blair GY, Bower CA (1954) Effect of bicarbonate on suitability of water for irrigation. Soil Sci 77:259-266

World Health Organization (WHO) (2011) Guidelines or drinking water quality, 4th edn. World Health Organization, Geneva, p 563

Yadav JP, Lata S (2004) Fluoride levels in drinking water sources in rural areas of block Jhajjar district, Jhajjar, Haryana. J Indian Water W Assoc 36:131-136

Yang S, Yang Q, Ma H, Liang J, Niu C, Martin JD (2018) Health risk assessment of phreatic water based on triangular fuzzy theory in Yinchuan plain. Ecotoxicol Environ Saf 164:732-738. https://doi. org/10.1016/j.ecoenv.2018.08.036

Zaman M, Shahid SA, Heng L (2018) Guideline for Salinity Assessment, Mitigation and Adaptation Using Nuclear and Related. Techniques. https://doi.org/10.1007/978-3-319-96190-3_5

Publisher's note Springer Nature remains neutral with regard to jurisdictional claims in published maps and institutional affiliations. 